\title{
Social Interaction Rescues Memory Deficit in an Animal Model of Alzheimer's Disease by Increasing BDNF- Dependent Hippocampal Neurogenesis
}

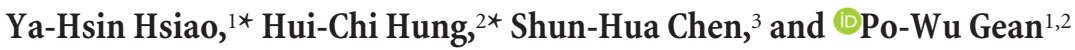 \\ ${ }^{1}$ Department of Pharmacology, College of Medicine, ${ }^{2}$ Institute of Basic Medical Science, and ${ }^{3}$ Department of Microbiology and Immunology, College of \\ Medicine, National Cheng Kung University, Tainan, Taiwan
}

It has been recognized that the risk of cognitive decline during aging can be reduced if one maintains strong social connections, yet the neural events underlying this beneficial effect have not been rigorously studied. Here, we show that amyloid precursor protein (APP) and presenilin 1 (PS1) double-transgenic (APP/PS1) mice demonstrate improvement in memory after they are cohoused with wild-type mice. The improvement was associated with increased protein and mRNA levels of BDNF in the hippocampus. Concomitantly, the number of $\mathrm{BrdU}^{+} / \mathrm{NeuN}^{+}$cells in the hippocampal dentate gyrus was significantly elevated after cohousing. Methylazoxymethanol acetate, a cell proliferation blocker, markedly reduced $\mathrm{BrdU}^{+}$and $\mathrm{BrdU} / \mathrm{NeuN}^{+}$cells and abolished the effect of social interaction. Selective ablation of mitotic neurons using diphtheria toxin (DT) and a retrovirus vector encoding DT receptor abolished the beneficial effect of cohousing. Knockdown of BDNF by shRNA transfection blocked, whereas overexpression of BDNF mimicked the memory-improving effect. A tropomyosin-related kinase B agonist, 7,8-dihydroxyflavone, occluded the effect of social interaction. These results demonstrate that increased BDNF expression and neurogenesis in the hippocampus after cohousing underlie the reversal of memory deficit in APP/PS1 mice.

Key words: adult neurogenesis; Alzheimer's disease; APP/PS1 mice; BDNF; memory decline; social interaction

\section{Introduction}

Alzheimer's disease $(\mathrm{AD})$ is a progressive neurodegenerative disease in which dementia symptoms gradually worsen over a number of years. The disease is characterized by accumulation of $\beta$-amyloid plaques and of tau tangles (Tiraboschi et al., 2004). At present, there is no definitive evidence to support that any particular treatment is effective in preventing or reversing the progression of the disease (Luchsinger and Mayeux, 2004). Often, we have been told that we can lower the risk of cognitive decline and the onset of $\mathrm{AD}$ if we maintain strong social connections and keep mentally active as we age (Stern, 2006; Szekely et al., 2007). Indeed, researchers have found a relationship between frequent social activity and better cognitive function (Stern, 2006; Szekely et al., 2007; Paradise et al., 2009). However, the underlying mechanisms are largely unknown.

It is established that neurogenesis occurs throughout life predominantly in the subgranular zone (SGZ) of the hippocampus

\footnotetext{
Received Feb. 23, 2014; revised 0ct. 14, 2014; accepted 0ct. 17, 2014.

Author contributions: Y.-H.H., S.-H.C., and P.-W.G. designed research; Y.-H.H., H.-C.H., and P.-W.G. performed research; Y.-H.H. and P.-W.G. analyzed data; Y.-H.H. and P.-W.G. wrote the paper.

This work was supported by Grant NHRI-EX101-10117NI from the National Health Research Institute and Grant NSC101-2321-B-006-025 from the National Science Council. We thank Marcus J. Calkins for proofreading the manuscript.

The authors declare no competing financial interests.

*Y.-H.H. and H.-C.H. contributed equally to this work.

Correspondence should be addressed to Dr. Po-Wu Gean, Department of Pharmacology, College of Medicine, National Cheng Kung University, Tainan, Taiwan 70101. E-mail: powu@mail.ncku.edu.tw.

DOI:10.1523/JNEUROSCI.0747-14.2014

Copyright $\odot 2014$ the authors $\quad 0270-6474 / 14 / 3416207-13 \$ 15.00 / 0$
}

and the subventricular zone of the lateral ventricle (Ming and Song, 2005; Balu and Lucki, 2009). In the SGZ region, new cells are differentiated into both neurons and glial cells and the newborn neurons incorporate to the granule cell layer of the dentate gyrus (DG; Lledo et al., 2006). A growing body of evidence supports the contribution of newborn neurons to hippocampusdependent memories (Shors et al., 2001; Saxe et al., 2006; Imayoshi et al., 2008). It has been reported that neurogenesis in the adult hippocampus is required for trace eyeblink conditioning (Shors et al., 2001). Moreover, ablated neurogenesis has been shown to impair contextual fear conditioning, but it was not shown to impair cued fear conditioning, which is independent of the hippocampus (Saxe et al., 2006; Imayoshi et al., 2008). However, conflicting results have also been reported. For example, ablation of hippocampal neurogenesis has no effect on tasks including contextual fear memory and Morris water maze (Shors et al., 2002; Snyder et al., 2005).

BDNF plays an important role in regulating the survival and differentiation of selective populations of neurons (Hetman et al., 1999), synaptic plasticity such as LTP (Korte et al., 1995; Pang et al., 2004), and learning and memory (Mizuno et al., 2000; Tokuyama et al., 2000). It has been shown that increases in the level of $B d n f$ mRNA and activation of BDNF signaling are associated with attenuation of stressor-induced reductions in neurogenesis within the DG (Furukawa-Hibi et al., 2011). Enhanced neurogenesis has been correlated with increases in the BDNF level in the DG (Telerman et al., 2011). We have previously 
shown that social isolation aggravates the impairment of contextual fear memory and the rundown of LTP in amyloid precursor protein (APP) and presenilin 1 (PS1) double-transgenic (APP/ PS1) mice (Hsiao et al., 2011). The purpose of this study was to evaluate how interaction with conspecifics affected the progression of $\mathrm{AD}$ in $\mathrm{APP} / \mathrm{PS} 1$ mice. Herein, we provide the first evidence that social interaction with conspecifics increases hippocampal levels of $B d n f$ mRNA and protein, resulting in increased neurogenesis and thereby rescuing memory deficits in APP/PS1 mice.

\section{Materials and Methods \\ Animals}

Male APP/PS1 mice (RRID:IMSR_MMRRC:034832) were obtained from the Jackson Laboratory and expressed both a chimeric mouse/human amyloid precursor protein (Mo/HuAPP695swe) and a mutant human presenilin 1 (PS1dE9) (Jankowsky et al., 2004). The mice were backcrossed to the C57BL/6J strain for six generations to create APP/PS1 transgenic mice. The APP/PS1 mice were housed in groups of 4-5 per cage $\left(27 \times 16 \times 12 \mathrm{~cm}^{3}\right)$ in a temperature-controlled vivarium on a $12 \mathrm{~h}$ reverse light/dark cycle. At 6 months old, an APP/PS1 mouse was randomly chosen to cohouse with a wild-type (WT) mouse (nontransgenic littermates of APP/PS1 mice) for 3 months. The APP/PS1 mouse that was cohoused with a 6-month-old APP/PS1 helper served as a control. All procedures on animals were approved by the Institutional Animal Care and Use Committee of the College of Medicine, National Cheng Kung University.

\section{Fear conditioning}

Fear conditioning was conducted in a specially designed chamber (Med Associates; $30 \times 24 \times 21 \mathrm{~cm}$ ) with a shock floor, house light, and speaker mounted on the wall through which tone presentations were delivered. Stainless-steel grids comprised the shock floor and were connected to a shock generator for foot shock delivery. All programs were controlled by FreezeScan software (Clever Systems). On the training day, APP/PS1 mice were transported to a behavioral room. After a $1 \mathrm{~h}$ habituation period in the room, the mice were placed in the training chamber for $120 \mathrm{~s}$. After the acclimation period, the mice were presented with a $20 \mathrm{~s}$ pure tone $(3 \mathrm{kHz})$ that coterminated with $3 \mathrm{~s}$ foot shock $(0.75 \mathrm{~mA})$. This procedure was repeated 4 times with an intertrial interval of $40 \mathrm{~s}$. After the last trial, the mice remained in the context for $2 \mathrm{~min}$ before being removed from the training chamber. The next day, the mice were returned to the training chamber for 3 min without exposure to either the tone or foot shock to measure contextual freezing. The mice were returned to their home cages at the end of the contextual test. The chamber was cleaned with $75 \%$ ethanol before each session. Behavior was recorded by video camera and freezing data were measured using FreezeScan software. Freezing was defined as the absence of any movement except for respiration and freezing levels were presented as a percentage time spent freezing.

\section{Social interaction test}

Social interaction behavior was evaluated in an open field apparatus made of clear Plexiglas $(40 \times 40 \times 30 \mathrm{~cm})$. Before testing, the open field apparatus was used to measure locomotor activity for $10 \mathrm{~min}$. Then, a small circular Plexiglas chamber (diameter: $9 \mathrm{~cm}$, height: $15 \mathrm{~cm}$ ) with numerous mesh-like holes (diameter: $1.2 \mathrm{~cm}$ ) was placed in the open field apparatus. The procedure for the social interaction test included 2 phases: habituation and testing. In the habituation period, each WT mouse (helper) was given $10 \mathrm{~min}$ to explore the environment freely. The WT mice were habituated for two days. On the third day, a WT mouse was also habituated for $10 \mathrm{~min}$ before testing. Immediately after habituation, a 6-month-old APP/PS1 mouse was enclosed in the small circular Plexiglas chamber. The sociability between the APP/PS1 and WT mouse was tested for $10 \mathrm{~min}$. The behavior of the mice was recorded by video camera. The total duration of contacts between the APP/PS1 and the WT mouse was measured using EthoVision 3.0 software (Noldus). The Plexi- glas barrier was only used to determine social interactions. In our study, a 6-month-old APP/PS1 mouse was paired with a WT mouse.

We also used a social interaction procedure adopted from Sams-Dodd (1995) and Snigdha and Neill (2008) to detect active social interactions and social aggression/attacks. Briefly, pairs of unfamiliar mice consisting of a 6-month-old APP/PS1 mouse and the helper were placed into the cage $\left(27 \times 16 \times 12 \mathrm{~cm}^{3}\right)$ for $10 \mathrm{~min}$. The time spent in social interactions (active contact such as sniffing, licking, close following, and grooming) was recorded for each pair of mice. We rarely observed instances of threatening behavior or biting (aggression) between the 6-month-old APP/PS1 mouse and the helper placed in the arena; aggression was thus excluded from the set of behavioral criteria used here.

We found memory improvement in the APP/PS1 mouse to be correlated with the social interaction time. Therefore, in the gain-of-function experiments, we chose a group of mice in which the interaction times between the APP/PS1 and the WT mouse were $<50$ s to avoid a ceiling effect. Conversely, in the loss-of-function experiments, we chose a group of mice in which the interaction times were $>100 \mathrm{~s}$ to avoid the floor effect. Gain-of-function experiments included overexpression of BDNF and tropomyosin-related kinase B (TrkB) agonist treatment with 7,8dihydroxyflavone (7,8-DHF), whereas loss-of-function experiments included ablation of neurogenesis [methylazoxymethanol acetate (MAM) and diphtheria toxin (DT) treatment] and knockdown of BDNF (see Fig. 5A).

\section{Morris water maze test}

In the training period, $18 \mathrm{APP} / \mathrm{PS} 1$ mice were trained to find a hidden submerged Plexiglas platform $(8 \mathrm{~cm}$ in diameter $)$ in a circular pool $(110$ $\mathrm{cm}$ in diameter, $50 \mathrm{~cm}$ deep) filled with water for 4 consecutive days with 4 trials per day. Each mouse was given $120 \mathrm{~s}$ to find the hidden platform in each trial. If the mouse found the platform within $120 \mathrm{~s}$, it was allowed to remain on the platform for $20 \mathrm{~s}$. If the mouse failed to find the platform within $120 \mathrm{~s}$, it was guided to the platform and allowed to rest on the platform for $20 \mathrm{~s}$. The latency was calculated as the average time to find the platform of the 4 trials per day. The memory retention test was conducted on the fifth day. The mouse was given $60 \mathrm{~s}$ to search a target quadrant. The behavior of the mice was monitored with a video camera connected to a computer. For data analysis, the pool was divided into four quadrants (target quadrant, left, right, and opposite of the target quadrant). The time spent in each quadrant was measured using EthoVision XT 5.1 software (Noldus).

\section{Spatial recognition memory test}

The object location memory test was performed as described previously (Stefanko et al., 2009). The procedure included 3 phases: habituation, training, and testing. A total of $27 \mathrm{APP} / \mathrm{PS} 1$ mice were habituated the experimental apparatus $(40 \times 40 \times 40 \mathrm{~cm})$ for $5 \mathrm{~min} / \mathrm{d}$ for 4 consecutive days before training. During the training trial, each mouse was placed in the apparatus and allowed to explore two identical objects for $10 \mathrm{~min}$. Spatial cues around the experimental apparatus were held constant throughout the experiment. After $24 \mathrm{~h}$, one object was moved to a novel location. During the testing trial, the mouse was placed into the apparatus to test retention memory for $5 \mathrm{~min}$. All objects and the experimental apparatus were cleaned with $75 \%$ ethanol to eliminate odor cues between trials. The behavior of the mice was recorded with a video camera mounted above the apparatus. For each set of video data, two investigators blind to the experimental conditions scored the time that the animal spent exploring each object. Object exploration time was defined as the duration during which the mouse directed its nose to the object, sniffed, or pawed the object. If the mouse was leaning against, standing, or sitting on the object, it was not recognized as exploration. To account for differences in exploratory behavior among the APP/PS1 mice, behavior was expressed as the discrimination index (DI). The DI was calculated according to the difference between the time exploring each object over the time exploring both objects $\left(\mathrm{DI}=\left(t_{\text {novel }}-t_{\text {familiar }}\right) /\left(t_{\text {novel }}+t_{\text {familiar }}\right) \times\right.$ 100) as reported previously (McQuown et al., 2011).

\section{Western blotting assay}

One hour after the contextual test, hippocampal tissue was dissected from the brains of the APP/PS1 mice. The hippocampal tissue samples 
A

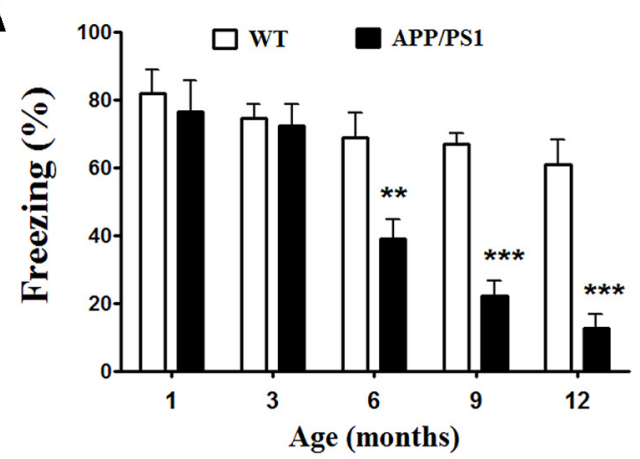

C

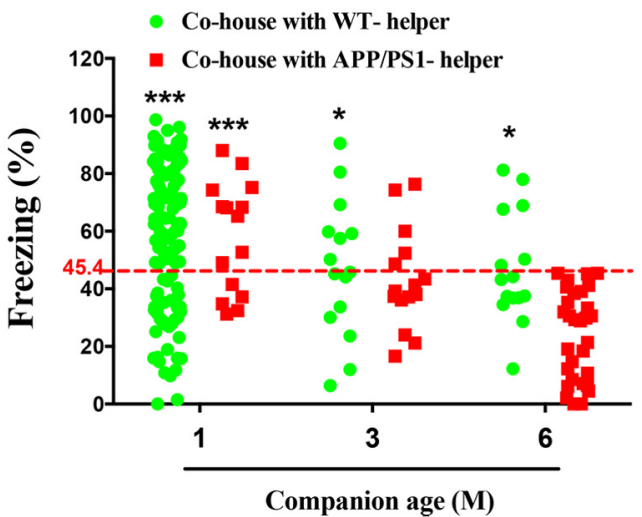

B
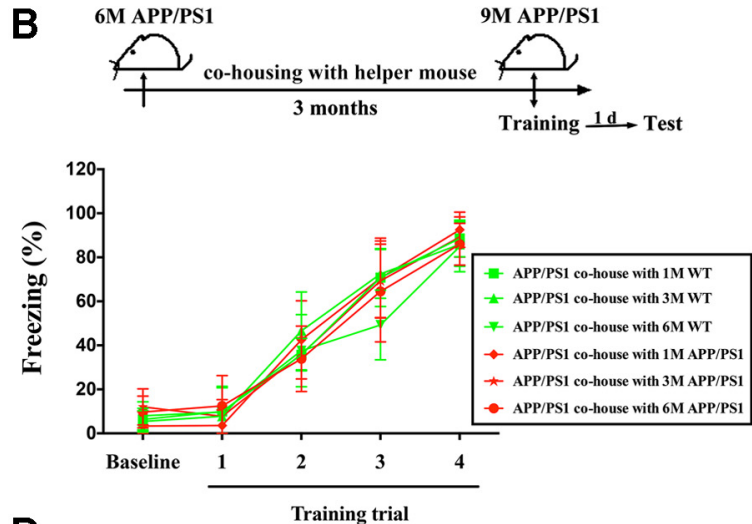

D

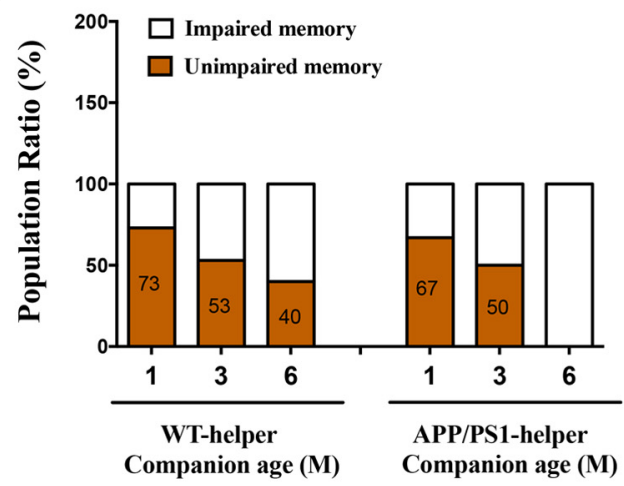

Figure 1. Reversal of contextual memory impairment in APP/PS1 mice after cohousing with WT mice. A. Age-dependent impairment of fear memory in APP/PS1 mice. APP/PS1 and WT mice at the ages of 1,3,6,9, and 12 months were given context footshock pairings, and memory retention was tested $24 \mathrm{~h}$ after training (WT groups: $n=6$ in $1 \mathrm{~m} ; n=7$ in 3 and $6 \mathrm{~m} ; n=8$ in 9 and $12 \mathrm{~m}$; APP/PS1 groups: $n=6$ in $1 \mathrm{~m} ; n=7$ in $3 \mathrm{~m} ; n=11$ in 6,9 , and $12 \mathrm{~m}) .{ }^{* *} p<0.01,{ }^{* * *} p<0.001$ vs WT mice of the same age. $B$, Six-month-old APP/PS1 mice cohoused with 1-, 3-, or 6- month-old WT and APP/PS1 helpers for 3 months were given context footshock pairings for conditioning. All experimental groups were able to acquire equivalent amounts of conditioned freezing during training. $C$, Contextual freezing responses of APP/PS1 mice after cohousing with 1-, 3-, or 6-month-old WT and APP/PS1 helpers for 3 months (cohousing with WT-helper groups: $n=117$ in $1 \mathrm{~m}, n=$ 15 in 3 and $6 \mathrm{~m}$; cohousing with APP/PS1-helper groups: $n=15$ in 1 and $3 \mathrm{~m}, n=30$ in $6 \mathrm{M}$ ). APP/PS1 mice that were cohoused with 6-month-old APP/PS1 helpers served as the control group. * $p<$ $0.05,{ }^{* * *} p<0.001$ vs cohousing with a 6-month-old APP/PS1-helper. D, Population ratio of APP/PS1 mice with either unimpaired memory or impaired memory after cohousing with 1-, 3-, or 6-month-old WT and APP/PS1 helpers for 3 months.

were homogenized using a cold lysis buffer (1\% Triton X-100, 0.1\% SDS, 50 mм Tris- $\mathrm{HCl}$, pH 7.5, $0.3 \mathrm{~m}$ sucrose, 5 mм EDTA, 2 mм sodium pyrophosphate, $1 \mathrm{~mm}$ sodium orthovanadate, and $1 \mathrm{~mm}$ enylmethylsulfonyl fluoride supplemented with a complete protease inhibitor mixture). After sonication, the lysates were centrifuged at $12000 \mathrm{rpm}$ for 30 min to obtain supernatants. The protein concentration of the supernatants was measured using a Bradford assay. Equal amounts of protein were separated by SDS-PAGE electrophoresis, transferred to a nitrocellulose membrane, and incubated in 5\% nonfat dry milk for $1 \mathrm{~h}$. Western blot analysis used BDNF (N20, 1:1000; Santa Cruz Biotechnology catalog \#sc-546 RRID:AB_630940) and actin (1:100 000; Milliporecatalog \#MAB1501 RRID:AB_2223041) antibodies reacted overnight at $4^{\circ} \mathrm{C}$, which were then incubated with HRP-conjugated secondary antibodies for $1 \mathrm{~h}$ at room temperature. The signal was detected by an ECL Plus detection reagent (PerkinElmer). The films were exposed at different times to obtain optimum density without saturation and were analyzed by densitometry. The protein levels were first normalized to internal control (actin) levels for each sample and then signal was calculated as a percentage of controls.

\section{Bdnf mRNA measurement}

One hour after the contextual test, hippocampal tissue samples were dissected from the brains of 12 APP/PS1 mice. A total RNA spin kit (Bioman) was used to extract total RNA from the hippocampal tissue samples and ImProm-II Reverse Transcription System (Promega) was used to synthesize cDNA. The mRNA of the $B d n f$ was measured with a TaqMan real-time quantitative reverse transcription PCR (RT-PCR) using a StepOnePlus System (Life Technologies). The BDNF probe (Mm04230607_s1) and GAPDH probe (Mm99999915_g1) were ob- tained from Life Technologies. The RT reactions were performed as follows: $50^{\circ} \mathrm{C}$ for $2 \mathrm{~min}, 95^{\circ} \mathrm{C}$ for $10 \mathrm{~min}$, followed by 40 cycles at $95^{\circ} \mathrm{C}$ for $15 \mathrm{~s}$ and $1 \mathrm{~min}$ at $60^{\circ} \mathrm{C}$. Gapdh was used as an endogenous control to standardize the amount of sample RNA. The levels of $B d n f$ mRNA were first normalized to Gapdh mRNA for each sample and then were measured as fold changes compared with control (9 M APP/PS1).

\section{Drugs}

BrdU labeling. To label the newborn neurons, APP/PS1 mice received an intraperitoneal injection of 5-bromo-2'-deoxyuridine (BrdU) $(300 \mathrm{mg} /$ $\mathrm{kg}$; Sigma-Aldrich) $2 \mathrm{~h}$ before cohousing with WT mice.

MAM treatment. To reduce the number of proliferating cells, $5 \mathrm{APP} /$ PS1 mice received an intraperitoneal injection of MAM $(7 \mathrm{mg} / \mathrm{kg}$; Midwest Research Institute) or 5 injected with vehicle (PBS) once per day for 7 consecutive days before cohousing with the WT mice.

DT treatment. Seven days before the completion of the cohousing phase of the experiment, groups of 5 APP/PS1 mice received daily injections of DT (16 $\mu \mathrm{g} / \mathrm{kg}$, i.p.; Sigma-Aldrich) or vehicle (PBS) once per day for 7 consecutive days.

7,8-DHF treatment. 7,8-DHF (Sigma-Aldrich) was first dissolved in dimethyl sulfoxide (DMSO) to generate a stock and then was diluted before application with the final 17\% DMSO concentration in PBS. Groups of $5 \mathrm{APP} / \mathrm{PS} 1$ mice received repeated intraperitoneal injections of 7,8-DHF ( $5 \mathrm{mg} / \mathrm{kg}$ ) or vehicle (17\% DMSO in PBS) once per day for 10 consecutive days before cohousing with the WT mice.

\section{Immunohistochemistry}

One hour after the contextual test, APP/PS1 mice were anesthetized with $10 \%$ chloral hydrate $(50 \mathrm{mg} / \mathrm{kg}$, i.p.). Mice were then perfused with PBS 
A
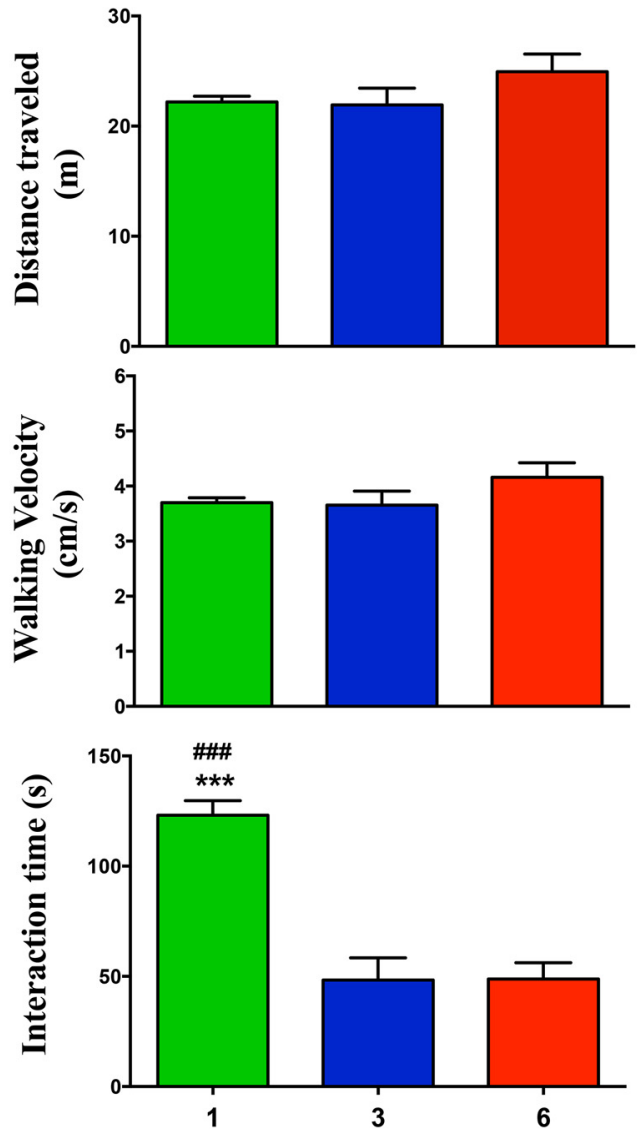

Age of WT-helper (months)
B

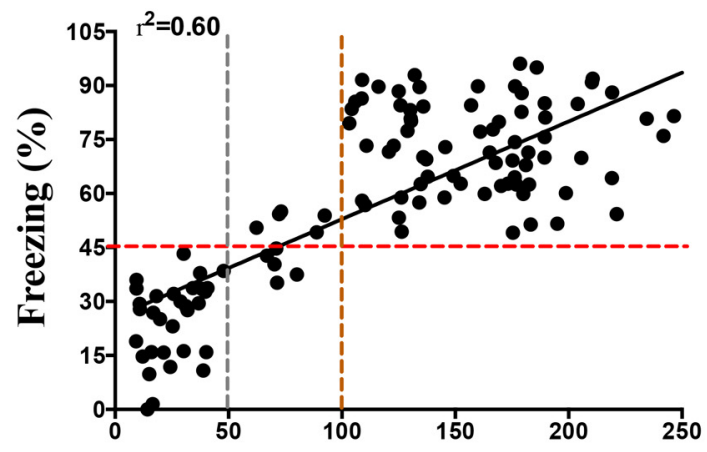

Interaction time of 1M WT-helper(s)

C

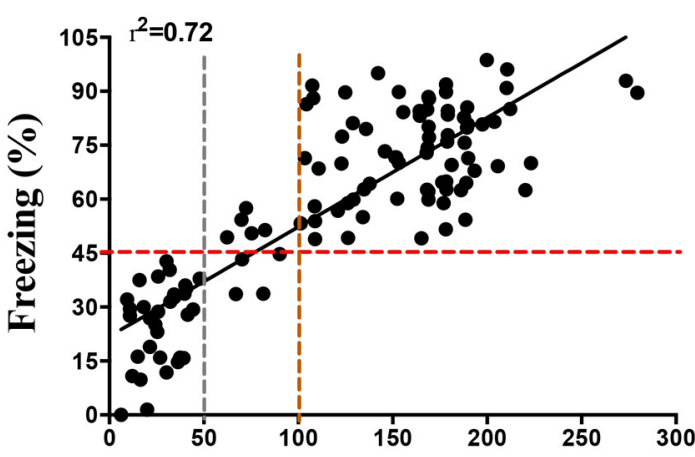

Interaction time between APP/PS1 and WT mice (s)

Figure 2. Social interaction contributes to the beneficial effect of cohousing. $A$, Walking velocity and travel distance were measured using an open field test. There were no differences found among the three helper groups. The time spent by the helper interacting with the APP/PS1 mice was measured for 10 min using a social interaction test $(n=117$ in 1-month-old WT-helper group, $n=15$ in 3-and 6-month-old WT helpers). ${ }^{* *} p<0.001$ vs 3 -month-old helper; \#\#\# $<0.001$ vs 6 -month-old helper. $\boldsymbol{B}$, Linear relationship between the interaction times of helpers and the contextual freezing responses of 9-month-old APP/PS1 mice after cohousing $\left(r^{2}=0.60 ; n=117\right)$. C, Plotting interaction times between APP/PS1 and 1-month-WT helpers versus the contextual freezing responses of 9-month-old APP/PS1 mice (after cohousing) revealed a linear relationship $\left(r^{2}=0.72 ; n=117\right)$.

followed by $4 \%$ paraformaldehyde (PFA). Brain was removed and postfixed in PFA at $4^{\circ} \mathrm{C}$ overnight, after which it was sectioned on a freezing microtome at $20 \mu \mathrm{m}$. For BrdU immunohistochemistry, sections were first rinsed with $\mathrm{PBS}$ containing $0.3 \%$ Triton X-100, pretreated with a saline-sodium citrate buffer at $85^{\circ} \mathrm{C}$ for $15 \mathrm{~min}$, incubated in $2 \mathrm{~N} \mathrm{HCl}$ at $37^{\circ} \mathrm{C}$ for $30 \mathrm{~min}$, and finally rinsed in $0.1 \mathrm{M}$ boric acid, $\mathrm{pH} 8.5$, at room temperature for $10 \mathrm{~min}$. Sections were incubated for $1 \mathrm{~h}$ in $3 \%$ bovine serum in PBS at room temperature, then overnight with primary antibodies, followed by $2 \mathrm{~h}$ incubation at room temperature with Alexa Fluor-conjugated secondary antibodies (1:200; Jackson ImmunoResearch). The primary antibodies used in this study were BrdU (1:100; Abcam catalog \#ab6326 RRID:AB_305426), NeuN (1:1000; Millipore catalog \#MAB377 RRID:AB_2298772, and GFP (1:1000; Pierce catalog \#PA1-18410 RRID:AB_1074875). For quantification, a systematic random counting procedure was used as described previously (Williams and Rakic, 1988). The rater was blind to the treatment of the mice. $\mathrm{BrdU}^{+} /$ $\mathrm{NeuN}^{+}$cells in the dentate granule cell layer (GCL) and the dentate SGZ were counted in a one-in-six series of sections (120 $\mu \mathrm{m}$ apart) throughout the dorsal hippocampus using a Leica DM 2500 microscope with a $40 \times$ objective. Twenty sections of DG per animal were analyzed. Data are presented as the total number of $\mathrm{BrdU}^{+} / \mathrm{NeuN}^{+}$cells per treatment group. The fluorescence images were obtained and analyzed using confocal microscopy (Olympus FV1000).

\section{Surgery}

Seventy-four APP/PS1 mice were anesthetized with $10 \%$ chloral hydrate $(50 \mathrm{mg} / \mathrm{kg}$, i.p.). The mice were mounted on a stereotaxic apparatus and the cannulas (26 gauge stainless steel tubing) were implanted into the DG (anteroposterior, $-2.0 \mathrm{~mm}$; mediolateral, $\pm 1.6 \mathrm{~mm}$; dorsoventral, -2.7 $\mathrm{mm}$ ). After $7 \mathrm{~d}$ recovery, the virus was administered bilaterally into the DG in a volume of $1 \mu \mathrm{l}$ at rate of $0.1 \mu \mathrm{l} / \mathrm{min}$.

\section{Lentivirus production}

To generate lentivirus, HEK293T cells were cotransfected with packaging plasmid containing gag, pol, and rev genes (pCMV- $\Delta$ R8.91), envelope plasmid (VSV-G expressing plasmid, pMD.G), and shRNA (Bdnf -shRNA or scrambled control shRNA) or cDNA (Bdnf cDNA) plasmid using Lipofectamine LTX (Life Technologies) according to the manufacturer's instructions. The lentivirus was harvested $48 \mathrm{~h}$ after transfection, purified, and concentrated to yield $1 \times 10^{8}$ to $1 \times 10^{9}$ infectious particles per milliliter. It was then administered to the DG of the APP/PS1 mice $7 \mathrm{~d}$ before cohousing with the WT mice. Silencing or enhancing gene expression achieved a significant difference $7 \mathrm{~d}$ after injection, which was confirmed by Western blotting analysis. In our study, we further confirmed the BDNF protein levels after cohousing.

For the BDNF knockdown, Bdnf short hairpin RNA (shRNA) clones were obtained from the National RNAi Core Facility (Institute of Molecular Biology, Academia Sinica, Taiwan). The target sequence for the Bdnf shRNA and scrambled control shRNA are described as follows: Bdnf shRNA: $5^{\prime}$ TGAGCGTGTGTGACAGTATTA-3'; Scrambled control shRNA: 5' TCCTAGAGAAAGTCCCGGTAT-3').

For BDNF overexpression, the mouse Bdnf cDNA ORF clone (NM_007540) was purchased from GenScript and subcloned into the cDNA expression lentivector (pLAS2.1w.PeGFP-I2-Puro) that was obtained from the National RNAi Core Facility (Institute of Molecular Biology, Academia Sinica, Taiwan). 
A

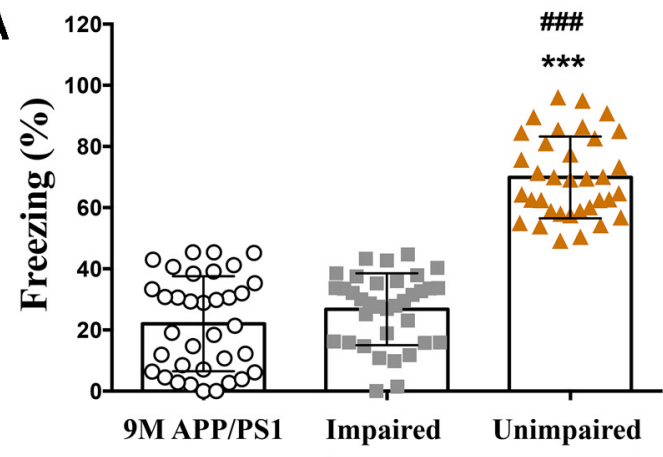

memory

C

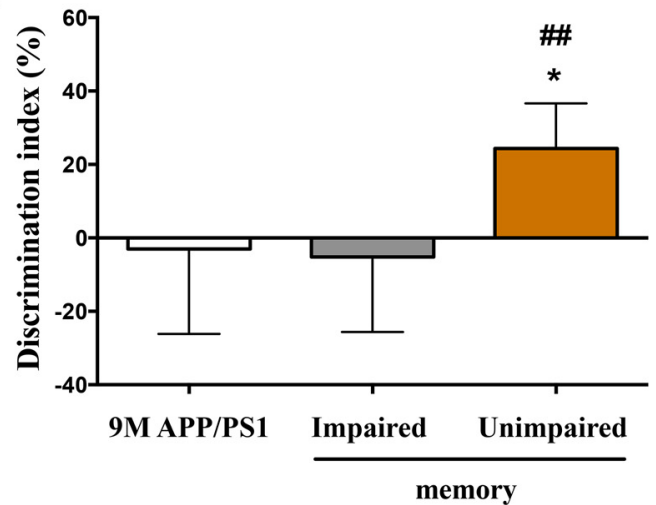

B

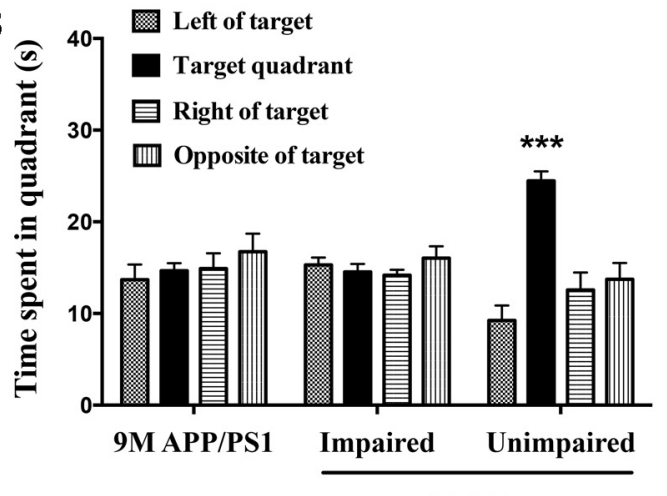

D

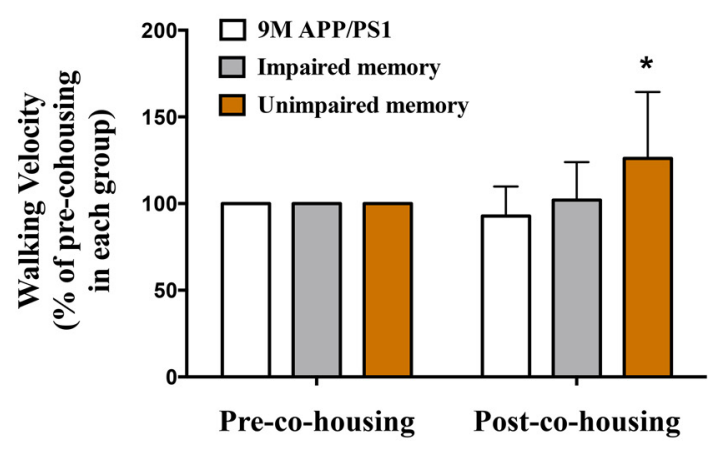

Figure 3. Increase in activity of APP/PS1 mice may account at least in part for the beneficial effect of housing with young mice. $A$, Contextual freezing responses of control, impaired, and unimpaired memory mice were performed ( $n=30$ in each group). APP/PS1 mice cohoused with 6-month-old APP/PS1 helpers served as the control group ( $9 \mathrm{~m}$ APP/PS1). ${ }^{* * *} p<0.001$ vs Control group, \#\#\# <0.001 vs Impaired memory group. $\boldsymbol{B}$, Probe test in Morris water maze. The quadrant search times for the control, impaired, and unimpaired memory mice were analyzed $(n=6$ in each group). Unimpaired memory mice spent longer in the target quadrant than the control and impaired memory mice. ${ }^{* * *} p<0.001$ vs Control and impaired memory mice. C, Spatial recognition memory test for the control, impaired, and unimpaired memory mice ( $n=9$ in each group). Two identical objects were placed in the arena and the mice were allowed to explore for 10 min. 0 ne of those objects was then moved to a different location and the mice were allowed to explore once more. The DI was calculated from the difference between the time for exploration of each object over the time spent exploring both objects ( $\left.\mathrm{DI}=\left(t_{\text {novel }}-t_{\text {familiar }}\right) /\left(t_{\text {novel }}+t_{\text {familiar }}\right) \times 100\right) .{ }^{*} p<0.05$ vs Control APP/PS1 mice, \#\#p $<0.01$ vs Impaired memory mice. $\boldsymbol{D}, 0$ pen field tests were performed before and after cohousing ( $n=9$ in each group). Only unimpaired memory mice showed increases in activity. ${ }^{*} p<0.05$ vs Precohousing.

DTR retrovirus production

To ablate newborn cells, DT receptor (DTR; human Hbegf, heparinbinding epidermal growth factor-like growth factor) cDNA ORF clone (NM_001945; GenScript) was inserted into retroviral vector pRetroXIRES-ZsGreen 1 (Clontech Laboratories). Retroviruses were produced in GP2-293 cells (Clontech Laboratories) that were cotransfected with retroviral vector pRetroX-IRES-ZsGreen 1 encoding DTR and pVSV-G (vesicular stomatitis virus glycoprotein) using Lipofectamine LTX (Life Technologies). The retroviruses were harvested $48 \mathrm{~h}$ after transfection, passed through a $0.45 \mathrm{~mm}$ filter, concentrated by Retro-X concentrator (Clontech Laboratories), and resuspended in PBS to yield $1 \times 10^{7}$ infectious particles per milliliter. The retrovirus was administered to the DG of the APP/PS1 mice at the age of 6 months before cohousing with the WT mice.

\section{Statistical analysis}

All values are shown as mean \pm SEM. Two-way ANOVA and Bonferroni's post hoc comparisons were used to analyze the differences in the freezing responses of the age-segregated APP/PS1 and WT mice. Oneway ANOVA and Bonferroni's post hoc comparisons were used to analyze the differences in freezing responses, protein level, and quantification of $\mathrm{BrdU}^{+} / \mathrm{NeuN}^{+}$cells among the control, impaired, and unimpaired memory groups. Comparisons between two groups were obtained using unpaired Student's $t$ test. A linear correlation between the two variables of interest was performed using the Pearson's correlation coefficient. The level of significance was $p<0.05$.

\section{Results}

Age-dependent impairment of fear memory in the APP/PS1 mice

Memory was assessed based on freezing behavior in the conditioned context that was previously paired with footshocks. APP/ PS1 and WT mice at 1, 3, 6, 9, and 12 months of age were given context footshock pairings and memory retention was tested $24 \mathrm{~h}$ after training. A two-way ANOVA revealed a main effect of genotype (WT vs APP/PS1 mice, $F_{(1,72)}=47.81, p<0.0001$ ), age $\left(F_{(4,72)}=18.08, p<0.0001\right)$, and a significant genotype-by-age interaction $\left(F_{(4,72)}=6.426, p=0.0002\right)$ (Fig. $1 A$ ). Post hoc analyses showed that the 6- to 12-month-old APP/PS1 mice exhibited significantly lower freezing responses than the age-matched WT mice. These results are in agreement with previous reports showing that the memory of APP/PS1 mice is normal at the age of 3 months and is impaired after the age of 6 months (Trinchese et al., 2004; Hsiao et al., 2011).

\section{Reversal of contextual memory deficit in APP/PS1 mice after cohousing with WT mice}

We investigated whether social interaction retarded AD progression by cohousing 6-month-old APP/PS1 mice with WT and APP/PS1 mice (helpers) for 3 months. The ages of the helpers were 1,3 , or 6 months. APP/PS1 mice that were cohoused with the same age APP/PS1 mice served as a control. To exclude the 
A

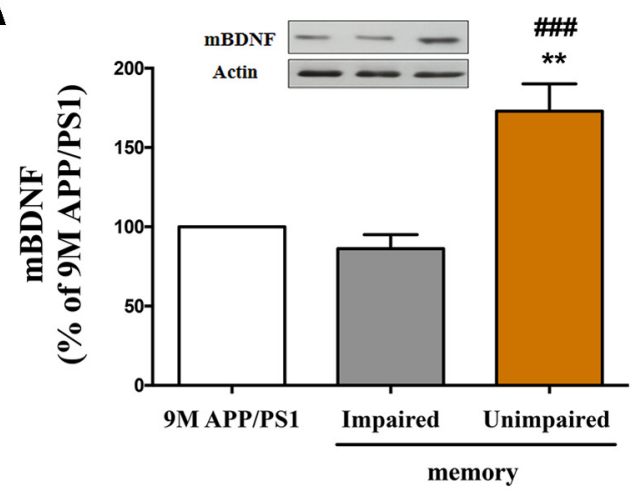

C

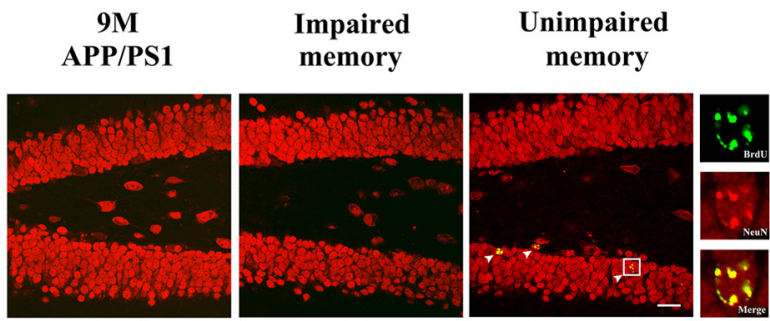

B

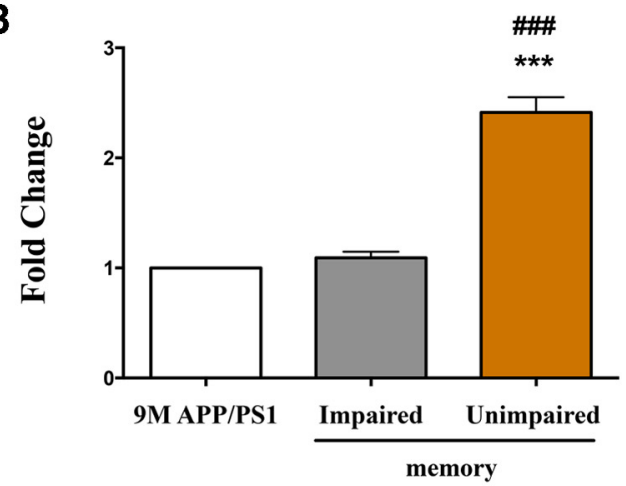

D

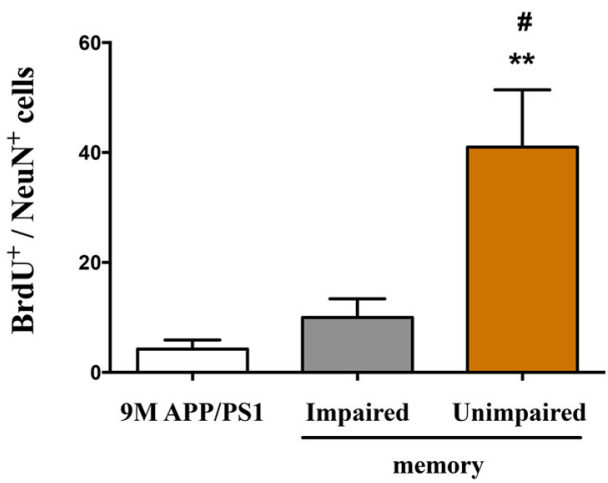

Figure 4. Social interaction with a helper increases BDNF protein, mRNA, and neurogenesis in APP/PS1 mice. Hippocampal BDNF protein $(\boldsymbol{A})$ and mRNA $(\boldsymbol{B})$ levels for unimpaired memory, impaired memory, and control APP/PS1 mice were determined using Western blotting ( $n=6$ in each group) and RT-PCR analysis ( $n=4$ in each group). ${ }^{* * *} p<0.001$ vs Control APP/PS1 mice,

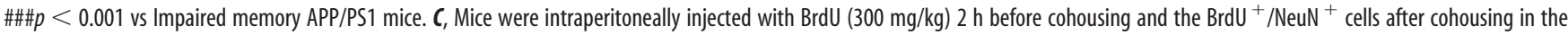
unimpaired memory, impaired memory, and control APP/PS1 mice were analyzed. Sections were doubly labeled with BrdU (green) and NeuN (red) immunofluorescence. Arrowheads in the

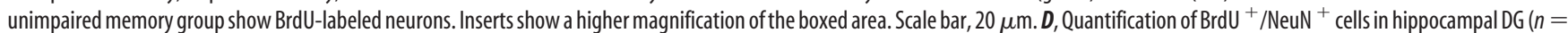
4 in each group). ${ }^{* *} p<0.01$ vs Control APP/PS1 mice, $\# p<0.05$ vs Impaired memory group.

possible complications introduced by copulation and reproduction, the APP/PS1 mice and helpers were the same sex (male). In the study, we chose WT mice rather than APP/PS1 mice as helpers to eliminate the potential influence of $\mathrm{AD}$ development in the helper mice after 3 months of companionship. As shown in Figure $1 B$, acquisition of conditioned freezing was similar in all experimental groups. However, when tested $24 \mathrm{~h}$ later, a two-way ANOVA revealed main effects related to helpers (WT vs APP/PS1 mice, $\left.F_{(1,201)}=4.921, p=0.0277\right)$, ages (1-, 3-, 6-month-old, $\left.F_{(2,201)}=12.00, p<0.0001\right)$, and a significant degree of interaction $\left(F_{(2,201)}=3.146, p=0.0451\right)$. Post hoc comparisons using Bonferroni corrections showed significant differences between groups that were cohoused with 6-month-old APP/PS1 mice (control mice) and those that were cohoused with the 1-monthold WT-helper group $(p<0.0001)$, the 3-month-old WT-helper group $(p=0.0181)$, the 6 -month-old WT-helper group $(p=$ $0.0195)$, and the 1-month-old APP/PS1-helper group $(p<$ $0.0001)$ (Fig. $1 C)$. Control APP/PS1 mice $(n=30)$ had the highest contextual freezing response $(45.4 \%)$. Therefore, we divided the APP/PS1 mice after cohousing into two groups: unimpaired memory mice with freezing responses $>45.4 \%$ and impaired memory mice with freezing responses $<45.4 \%$. After cohousing with 1-, 3-, or 6-month-old WT mice or 1- or 3- month-old APP/PS1 mice for 3 months, there were 73\%, 53\%, 40\%, 67\%, and $50 \%$ of APP/PS1 mice with unimpaired memory, respectively (Fig. 1D). These results indicate that cohousing with a helper has a beneficial effect on the memory of APP/PS1 mice and that this effect is more dramatic after cohousing with a 1-monthold helper than it is with a 6-month-old helper.

\section{Social interaction contributes to the beneficial effect of cohousing}

To investigate factors accounting for the beneficial effect of cohousing, we measured walking velocity and travel distance using an open field test. We found that there was no difference among the 3 WT helper groups (Fig. 2A). We next performed a social interaction test between the APP/PS1 mice and the helpers. The WT mice were tested for $10 \mathrm{~min}$ in an empty cage consisting of a central compartment containing an APP/PS1 mouse in a small Plexiglas chamber. The one-way ANOVA for interaction time showed a main group effect $\left(F_{(2,144)}=14.40, p<0.0001\right)$, with 1 -month-old helpers spending a longer time interacting with the APP/PS1 mice than the 3-month-old helpers $(p<0.0001)$ and 6 -month old helpers $(p<0.0001)$ (Fig. $2 A)$. In addition, there was a linear relationship between the interaction times of helpers and the contextual freezing responses of the 9-month-old APP/ PS1 mice after cohousing $\left(r^{2}=0.60, p<0.0001\right.$; Fig. $\left.2 B\right)$. These results suggest that social interaction contributes to the beneficial effect of cohousing.

We also tested the mice using a social interaction procedure adopted from Sams-Dodd (1995) and Snigdha and Neill (2008). Briefly, pairs of unfamiliar 6-month-old APP/PS1 mouse and a helper were placed into a cage for $10 \mathrm{~min}$. The time spent in social interaction (active contact such as sniffing, licking, close following, and grooming) was recorded for each pair of mice. As shown in Figure $2 C$, there was a linear relationship between the interaction times of helpers and the contextual freezing responses of the 9-month-old APP/PS1 mice after cohousing $\left(r^{2}=0.72, p<\right.$ $0.0001)$. 


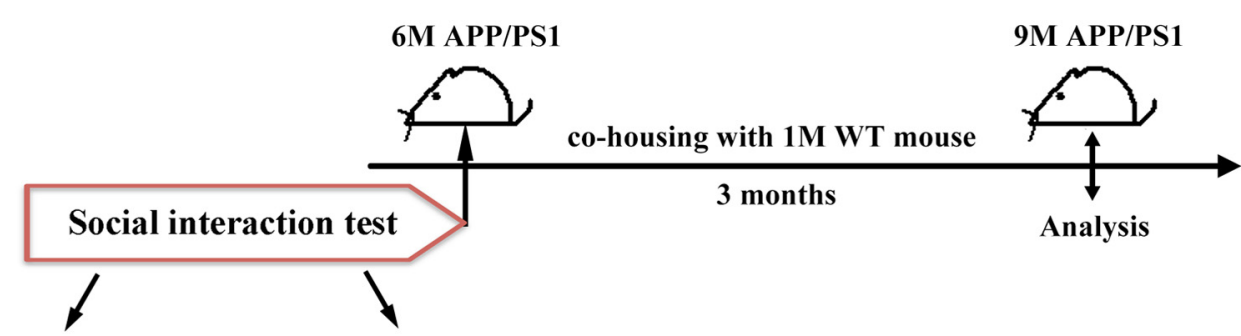

Interaction time $<50 \mathrm{~s}$

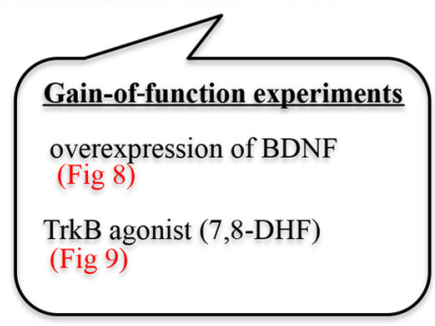

B

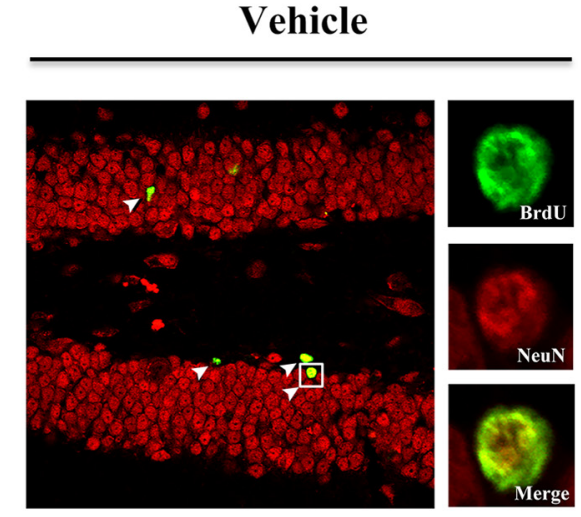

C

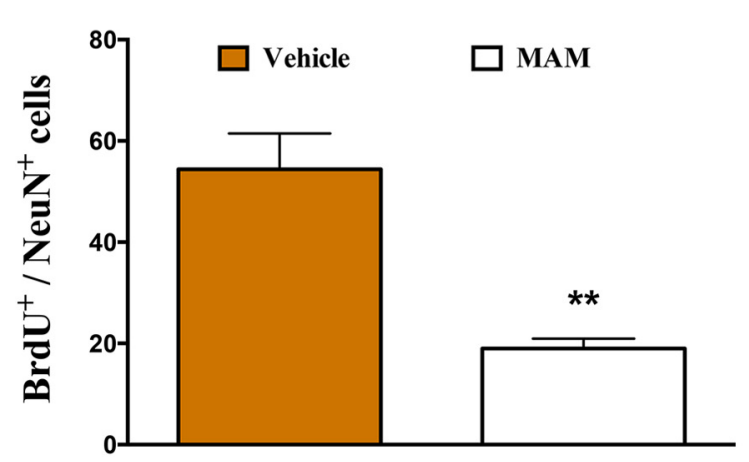

Interaction time $>100 \mathrm{~s}$

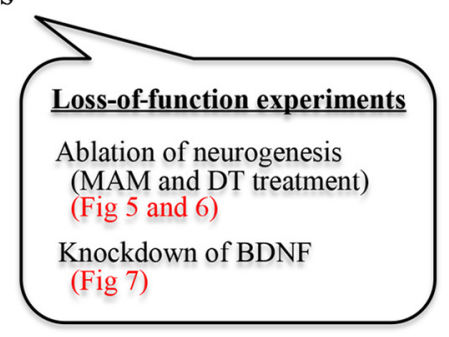

MAM

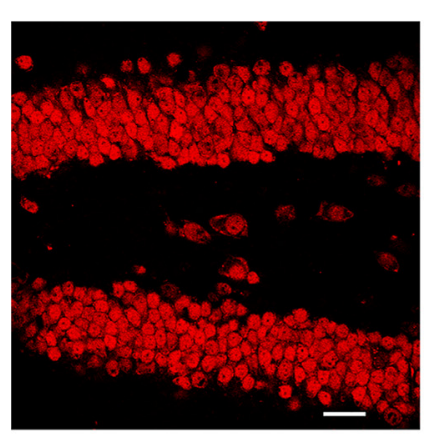

D

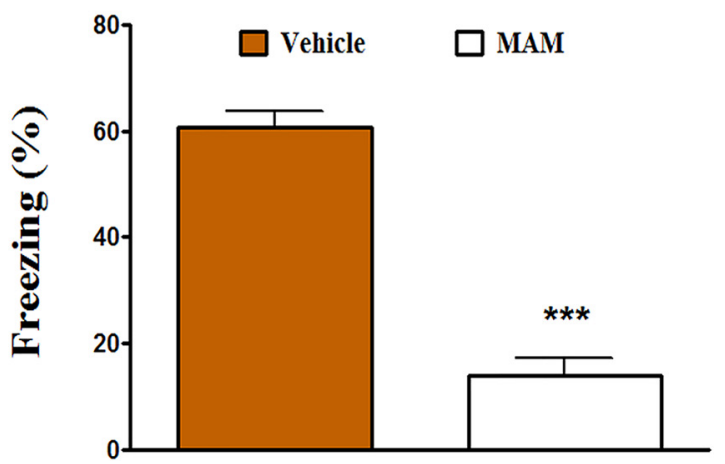

Figure 5. Social interaction with a helper increases neurogenesis in APP/PS1 mice as confirmed by MAM. $A$, Timeline of gain-of-function and loss-of-function experiments. $B$, APP/PS1 mice received an intraperitoneal injection of MAM $(7 \mathrm{mg} / \mathrm{kg}$ ) or a vehicle once per day for $7 \mathrm{~d}$. Twenty-four hours after the last injection, the mice were intraperitoneally injected with BrdU ( $300 \mathrm{mg} / \mathrm{kg}$ ) $2 \mathrm{~h}$ before cohousing and the $\mathrm{BrdU}^{+} / \mathrm{NeuN}^{+}$cells were analyzed after cohousing. Sections were doubly labeled with BrdU (green) and NeuN (red) immunofluorescence. Arrowheads in the vehicle group show BrdU-labeled neurons. Inserts show a higher magnification of the boxed area. Scale bar, $20 \mu \mathrm{m}$. C, Quantification of BrdU ${ }^{+} / \mathrm{NeuN}^{+}$cells in the DG ( $n=5$ in each group). .** $p<0.01$ vs Vehicle. $\boldsymbol{D}$, Freezing responses were assessed in MAM- or vehicle-treated mice ( $n=5$ in each group). ${ }^{* * *} p<0.001$ vs Vehicle.

Based on the beneficial effect of cohousing, we chose 1-month-old WT mice as a companion model and divided the APP/PS1 mice after cohousing into two groups: unimpaired memory mice with freezing responses $>45.4 \%$ and impaired memory mice with freezing responses $<45.4 \%$ (Fig. $3 A$ ). To further elucidate the cohousing effect on memory, control, impaired memory, and unimpaired memory, APP/PS1 mice were assessed using an invisible platform task in the Morris water maze test. The control and impaired memory APP/PS1 mice were unable to learn the hidden-platform task efficiently. The escape latencies were unchanged after $4 \mathrm{~d}$ of training. The unimpaired memory APP/PS1 mice also exhibited unchanged escape latency on the first $3 \mathrm{~d}$ of training, but significantly improved their learning ability on the fourth day of training $\left(F_{(2,15)}=4.421, p=0.031\right)$. Assessment of memory recall for the platform location on the probe trial revealed that the unimpaired memory mice spent a significantly longer time in the quadrant that formerly contained the hidden platform $\left(F_{(2,15)}=38.68, p<0.0001\right.$; Fig. $\left.3 B\right)$. These 
A

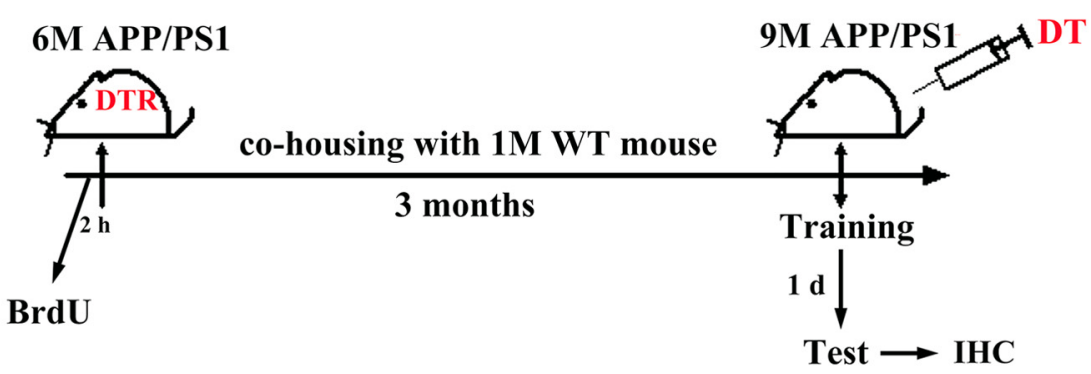

B

Vehicle

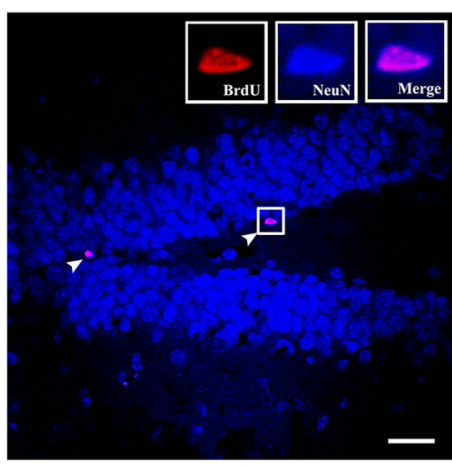

C

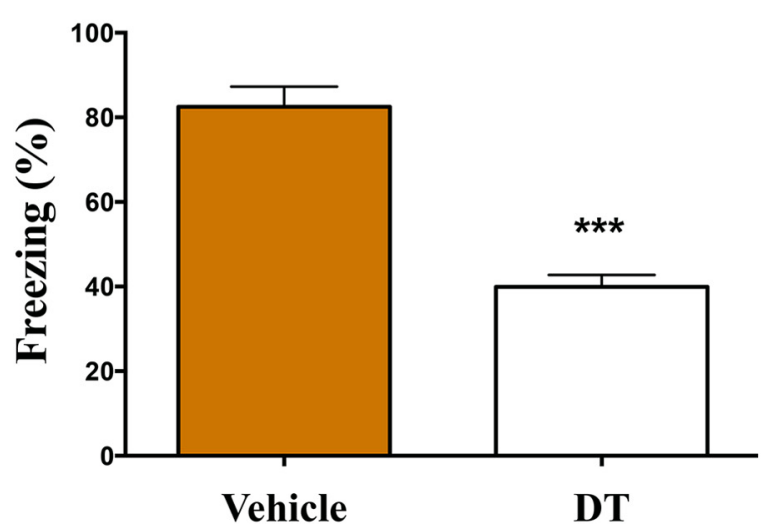

DT
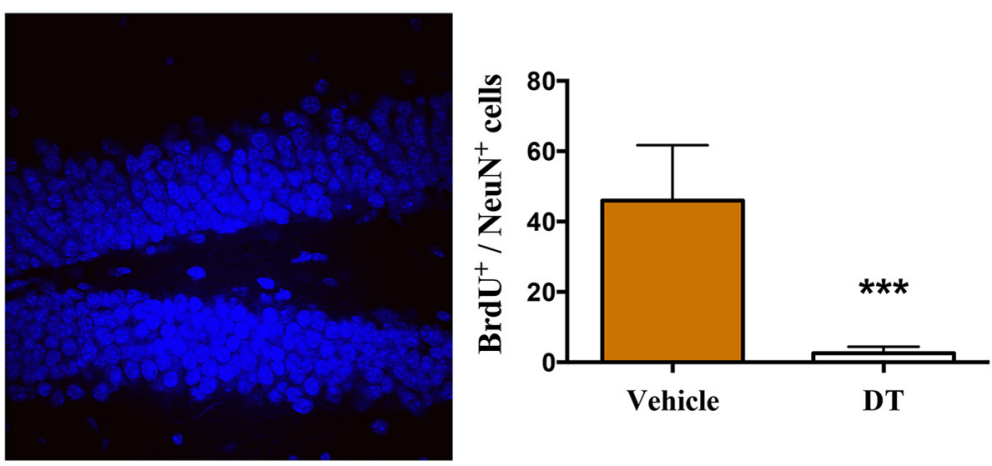

D

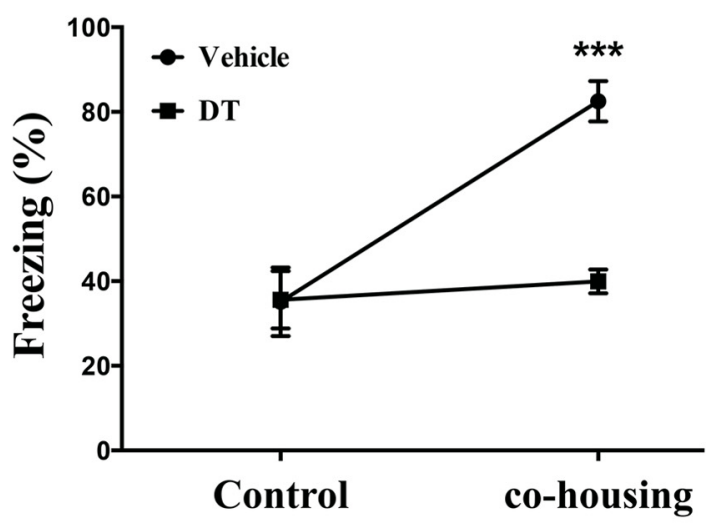

Figure 6. Ablation of newborn neurons blocks cohousing-induced memory improvement. $A$, A retrovirus vector that encoded DTR was injected bilaterally into mouse DG before cohousing. DT or a vehicle was injected once per day for $7 \mathrm{~d}$ before completion of cohousing. $\boldsymbol{B}$, Sections were doubly labeled with BrdU (red) and NeuN (blue) immunofluorescence. Arrowheads in the vehicle group show the BrdU-labeled neurons. Inserts show a higher magnification of the boxed area. Scale bar, $20 \mu \mathrm{m}$. $C$, Contextual fear responses were assessed after administration of DT ( $n=5 \mathrm{in}$ each group). ${ }^{* * *} p<0.001$ vs Vehicle. $\boldsymbol{D}$, Effect of DT on freezing responses in the APP/PS1 mice with or without cohousing. DT did not affect freezing responses in the control APP/PS1 mice without cohousing. Selective ablation of mitotic neurons using the DT-DTR system abolished the beneficial effect of companionship ( $n=5$ in each group). ${ }^{* * *} p<0.001$ vs Control APP/PS1 mice.

results demonstrate rescue of spatial memory recall after cohousing. Analysis of the effect of group on swim speed was measured over the 4 training days and there was no difference found among the 3 groups $\left(F_{(2,15)}=0.2741, p=0.764\right)$.

We also conducted a spatial recognition memory test that more specifically involved the hippocampus (Barker and Warburton, 2011). Two identical familiar objects were placed in the arena and the mice were allowed to explore. One of those objects was then moved to a different location and the mice were allowed to explore once more. As shown in Figure $3 C$, both the impaired memory and control mice explored both objects similarly, resulting in a near zero discrimination index. In contrast, the unimpaired memory mice spent a significantly longer time exploring the new location object $\left(F_{(2,24)}=6.235, p=0.0051\right)$. To deter- mine whether the beneficial effect of housing young mice with the APP/PS1 mice was the result of increased activity in the APP/ PS1 mice, we measured activity levels of the APP/PS1 mice after cohousing. As shown in Figure 3D, only the unimpaired memory group increased activity after cohousing.

Social interaction with a helper increases BDNF protein and mRNA levels in the hippocampus of the APP/PS1 mice Selective reduction of $B d n f \mathrm{mRNA}$ and protein levels in the hippocampus has been reported in AD patients (Phillips et al., 1991; Narisawa-Saito et al., 1996; Ferrer et al., 1999; Zuccato and Cattaneo, 2009). To determine whether the cohousing-induced improvement in the memory of APP/PS1 mice is dependent on the action of hippocampal BDNF, we quantified hippocampal BDNF 


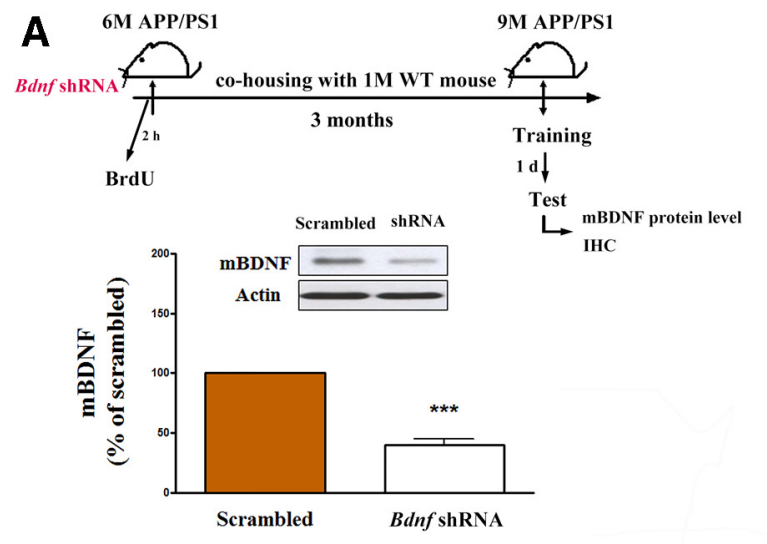

B

C

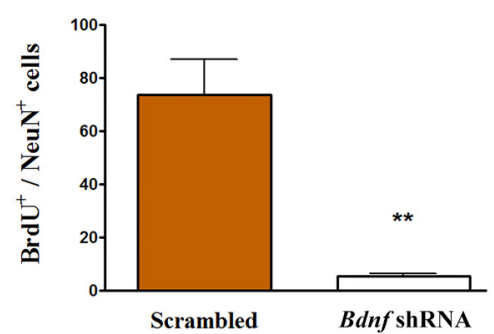

D

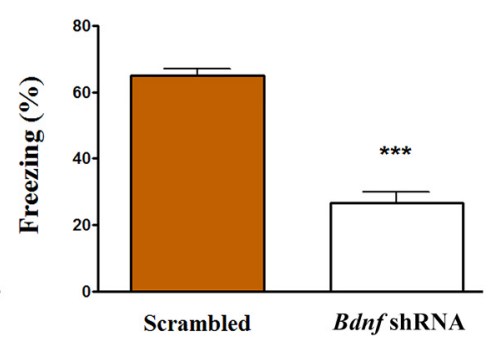

E

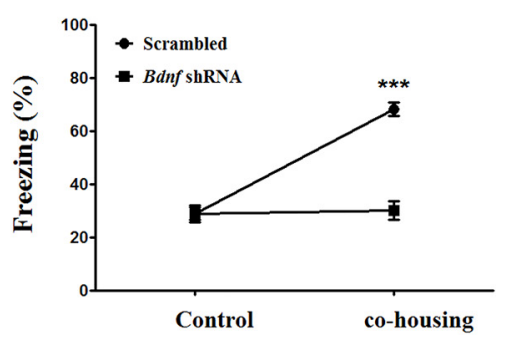

Figure 7. Effects of knockdown of BDNF on cohousing-induced reversal of memory impairment. $A$, Mice were injected with Bdnf shRNA or scrambled control shRNA into the DG $7 \mathrm{~d}$ before cohousing. mBDNF protein levels were measured using a Western blotting analysis after cohousing ( $n=5$ in each group). ${ }^{* * *} p<0.001$ vs $S$ crambled control shRNA. $\boldsymbol{B}$, Mice were intraperitoneally injected with BrdU ( $300 \mathrm{mg} / \mathrm{kg}$ ) $2 \mathrm{~h}$ before cohousing and the BrdU ${ }^{+} / \mathrm{NeuN}^{+}$cells were analyzed after cohousing. Sections were doubly labeled with BrdU (red) and NeuN (blue) immunofluorescence. Arrowheads in the scrambled control shRNA group show BrdU-labeled neurons. Inserts show a higher magnification of the boxed area. Scale bar, $20 \mu \mathrm{m}$. C, Quantification of BrdU ${ }^{+} / \mathrm{NeuN}^{+}$ cells in the $D G\left(n=4\right.$ in each group). ${ }^{* *} p<0.01$ vs Scrambled control shRNA. $\boldsymbol{D}$, Contextual fear responses were assessed after cohousing ( $n=9$ in each group). ${ }^{* * *} p<0.001$ vs $S$ crambled control shRNA. $E$, Effect of Bdnf shRNA treatment on freezing responses in APP/PS1 mice with or without cohousing. Bdnf shRNA treatment did not affect freezing responses in control APP/PS1 mice in the absence of cohousing with WT mice ( $n=9$ in each group). ${ }^{* * *} p<0.001$ vs Control APP/PS1 mice.

protein levels. A group of 6-month-old APP/PS1 mice was cohoused with 1-month-old WT helpers for 3 months. These APP/ PS1 mice were divided into unimpaired memory and impaired memory mice according to the criterion described above. Western blotting analysis revealed that the mature BDNF level in the unimpaired memory mice was significantly higher than that of the control and impaired memory mice $\left(F_{(2,15)}=\right.$ 17.44, $p=0.0001$; Fig. $4 A$ ). In parallel experiments, we also measured $B d n f$ mRNA levels in separate unimpaired and impaired memory mice and found that $B d n f$ mRNA level in unimpaired memory mice was significantly higher than that of the control and impaired memory mice $\left(F_{(2,9)}=85.58, p<\right.$ 0.0001; Fig. 4B).

\section{Social interaction with a helper increases neurogenesis in APP/PS1 mice}

It is known that hippocampal BDNF modulates neurogenesis and behavior in mice (Shors et al., 2001; Shors et al., 2002; Saarelainen et al., 2003). We investigated whether neurogenesis in the hippocampus is involved in cohousing-induced improvement of memory in APP/PS1 mice. Mice were intraperitoneally injected with BrdU $(300 \mathrm{mg} / \mathrm{kg}) 2 \mathrm{~h}$ before cohousing and BrdU ${ }^{+}$cells were analyzed after cohousing (Fig. 4C). To determine whether cohousing has any effect on the differentiation of $\mathrm{BrdU}^{+}$cells, we performed a double labeling with antibodies against BrdU and the neuronal marker NeuN. One-way ANOVA showed a main effect of group $\left(F_{(2,9)}=9.578, p=0.0059\right)$. Post hoc tests revealed that the number of $\mathrm{BrdU}^{+} / \mathrm{NeuN}^{+}$cells in the unimpaired memory mice was significantly higher than that in the impaired mem- ory mice $(p=0.0225)$ and control APP/PS1 mice $(p=0.0084)$ (Fig. 4D).

\section{Neurogenesis is required for memory improvement in APP/} PS1 mice after cohousing

We determined the relationship between neurogenesis and memory improvement using the cell proliferation blocker MAM (Shors et al., 2001). We found that if the interaction times between the APP/PS1 and WT mouse were $>100 \mathrm{~s}$, the APP/PS1 mouse typically exhibited unimpaired memory after 3 months of companionship. On the contrary, cohousing did not rescue the memory of the APP/PS1 mouse when the interaction times were $<50$ s (Fig. $2 B, C$ ). Therefore, we used a social interaction test as a criterion in gain-of-function and loss-of-function experiments (Fig. 5A). To consider the inhibitory effect of MAM, APP/PS1 mice of interaction times $>100 \mathrm{~s}$ were given intraperitoneal injections of MAM ( $7 \mathrm{mg} / \mathrm{kg}$ ) or a vehicle once per day for $7 \mathrm{~d}$. Twenty-four hours after the last injection, the APP/PS1 mice were intraperitoneally injected with BrdU (300 mg/kg) $2 \mathrm{~h}$ before cohousing and the $\mathrm{BrdU}^{+}$cells were analyzed after cohousing. Figure 5, $B$ and $C$, shows that the $\mathrm{BrdU}^{+} / \mathrm{NeuN}^{+}$cells decreased markedly in the MAM-treated APP/PS1 mice $\left(t_{(8)}=4.824, p=\right.$ $0.0013)$. Importantly, the contextual freezing response in the MAM-treated APP/PS1 mice was significantly lower than that in the vehicle-treated APP/PS1 mice $\left(t_{(8)}=10.39, p<0.0001\right.$; Fig. $5 D)$. Furthermore, the freezing response of MAM-treated APP/ PS1 mice was not different from that of control APP/PS1 mice ( $p>0.1$, data not shown). These results suggest that neurogen- 


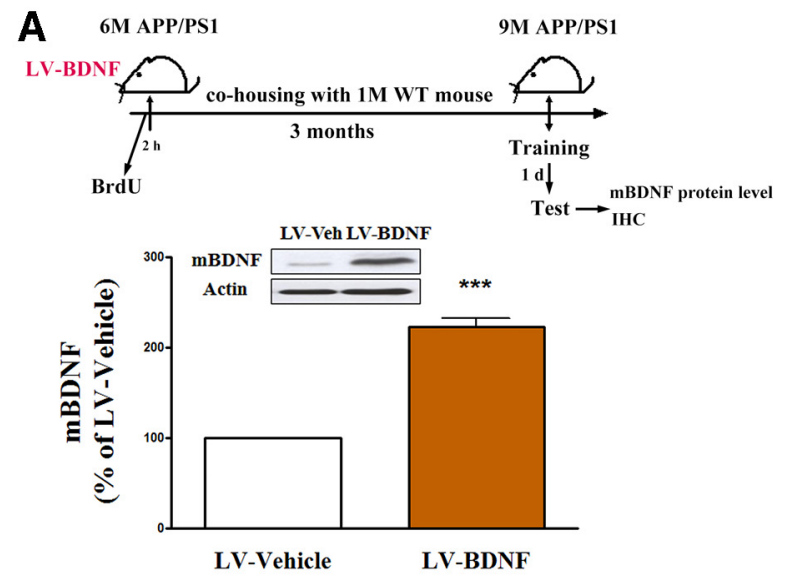

B
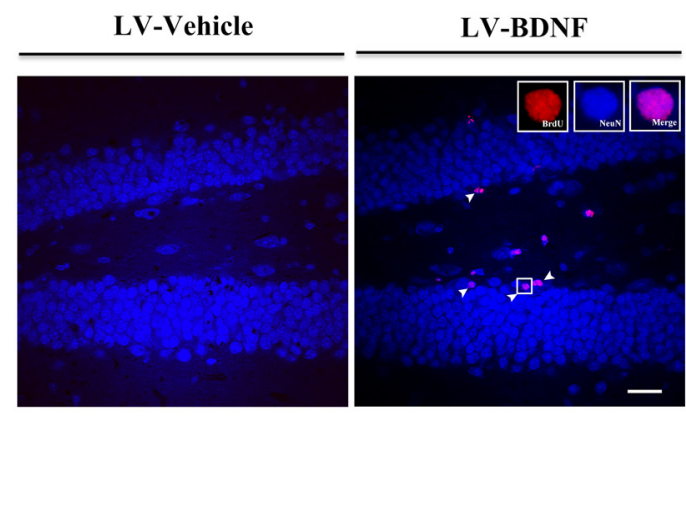

C

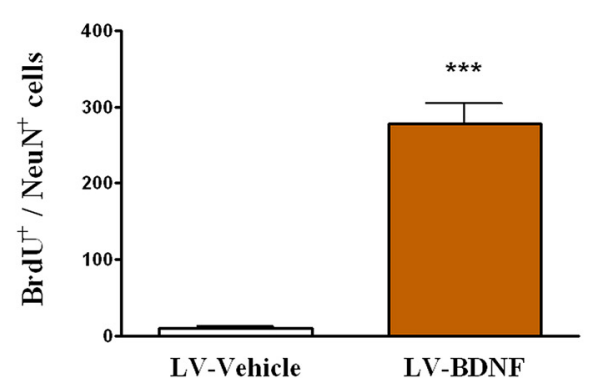

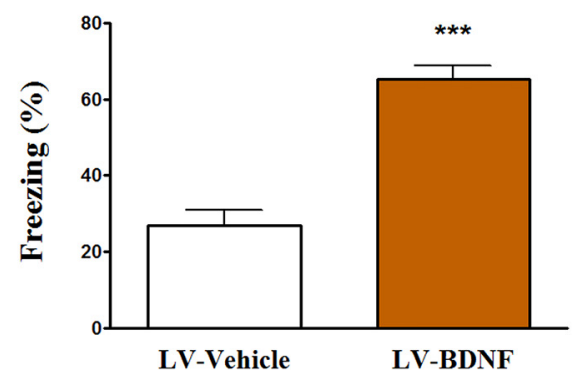

Figure 8. Effect of BDNF overexpression on cohousing-induced reversal of memory impairment. $A, L V$-BDNF or LV-Vehicle was injected into mouse DG $7 \mathrm{~d}$ before cohousing, and mBDNF level was measured after cohousing ( $n=5$ in each group). ${ }^{* * *} p<0.001$ vs LV-Vehicle. B, Mice were intraperitoneally injected with BrdU ( $\left.300 \mathrm{mg} / \mathrm{kg}\right) 2 \mathrm{~h}$ before cohousing and BrdU ${ }^{+} / \mathrm{NeuN}{ }^{+}$cells were analyzed after cohousing. Sections were doubly labeled with BrdU (red) and NeuN (blue) immunofluorescence. Arrowheads in the LV-BDNF group show BrdU-labeled neurons. Inserts show a higher magnification of the boxed area. Scale bar, $20 \mu \mathrm{m}$. C, Quantification of BrdU ${ }^{+} /$NeuN $^{+}$cells in the DG ( $n=4$ in each group). ${ }^{* * *} p<0.001$ vs LV-Vehicle. D, LV-BDNF-treated mice exhibited significantly higher freezing responses compared with the LV-vehicle mice ( $n=9$ in each group). ${ }^{* *} p<0.001$ vs LV-Vehicle.

esis in the hippocampal DG is required for the rescue of memory impairment in APP/PS1 mice.

Apoptosis is induced after DT binds to the DTR (Dorland et al., 1979). To further investigate the role of newborn neurons in cohousing-induced memory improvement, we injected a retrovirus vector encoding DTR into the DG, which allowed us to tag and target mitotic neurons for subsequent ablation (Han et al., 2009; Arruda-Carvalho et al., 2011). Mitotic neurons with DTR were primed to undergo apoptotic cell death once the DT was bound to the receptor. Either DT or vehicle was injected once per day for $7 \mathrm{~d}$ before completion of cohousing (Fig. 6A). As shown in Figure $6 B$, administration of DT significantly reduced $\mathrm{BrdU}^{+} /$ $\mathrm{NeuN}^{+}$cells in the DG. Concomitantly, the freezing response in DT-treated animals was significantly lower than that of vehicletreated mice $\left(t_{(8)}=6.140, p=0.0003\right.$; Fig. $\left.6 C\right)$. In contrast, DT treatment did not affect freezing responses in the control APP/ PS1 mice without cohousing (Fig. 6D). These data show that the improvement of memory after cohousing can be abolished by decreasing neurogenesis.

Rescue of contextual memory by social interaction is mediated by BDNF-dependent hippocampal neurogenesis To further investigate the role of BDNF in regard to the cohousing effect, we performed loss-of-function experiments using $B d n f$-specific shRNAs and chose APP/PS1 mice in which interaction times with the WT mice were $>100 \mathrm{~s}$. We injected $B d n f$ shRNA or scrambled control shRNA into the DG $7 \mathrm{~d}$ before cohousing. After cohousing, Western blotting analysis showed that mBDNF levels were markedly reduced in $B d n f$ shRNAtreated mice compared with those treated with scrambled control
shRNA $\left(t_{(5)}=11.41, p<0.0001\right.$; Fig. $\left.7 A\right)$. In parallel, $\mathrm{BrdU}^{+} /$ $\mathrm{NeuN}^{+}$cells were markedly decreased in $B d n f$ shRNA-treated mice $\left(t_{(6)}=5.057, p=0.0023\right.$; Fig. $\left.7 B, C\right)$. Importantly, the freezing responses of $B d n f$ shRNA-treated mice were significantly lower than those of the scrambled control shRNA-treated mice $\left(t_{(16)}=9.772, p<0.0001\right.$; Fig. $\left.7 D\right)$. It was noted that the $B d n f$ shRNA treatment did not affect freezing responses in the control APP/PS1 mice (Fig. 7E).

To overexpress BDNF, we cloned the mouse $B d n f$ gene into a lentivirus (LV) vector (LV-BDNF) and an empty vector (LVVehicle) served as the control. The LV-BDNF or LV-Vehicle was injected into the DG $7 \mathrm{~d}$ before cohousing. mBDNF protein was measured after cohousing. In this experiment, we selected APP/ PS1 mice with interaction times with the WT mice that were $<50$ s. As shown in Figure $8 A, \mathrm{mBDNF}$ protein levels were significantly increased in the LV-BDNF-treated mice $\left(t_{(5)}=13.00, p<\right.$ $0.0001)$. In parallel, the $\mathrm{BrdU}^{+} / \mathrm{NeuN}^{+}$cells were greater in $\mathrm{LV}$ BDNF-treated mice $\left(t_{(6)}=9.625, p<0.0001\right.$ ) (Fig. $\left.8 B, C\right)$. LVBDNF-treated mice also exhibited significantly higher freezing responses than the LV-Vehicle mice $\operatorname{did}\left(t_{(16)}=7.150, p<\right.$ 0.0001; Fig. 8D).

If BDNF upregulation is indeed a major cause of the cohousing effect, one would expect memory improvement from administration of BDNF functional mimetics in the APP/PS1 mice. A small-molecule TrkB agonist, 7,8-DHF ( $5 \mathrm{mg} / \mathrm{kg}$, i.p.; Jang et al., 2010; Devi and Ohno, 2012), was injected once per day for $10 \mathrm{~d}$ before cohousing. In this experiment, we selected APP/PS1 mice with interaction times with the WT mice that were $<50 \mathrm{~s}$. As shown in Figure $9 A$, the level of phosphorylated TrkB, an activated form of the TrkB receptor, in the hippocampus was significantly higher in 
A
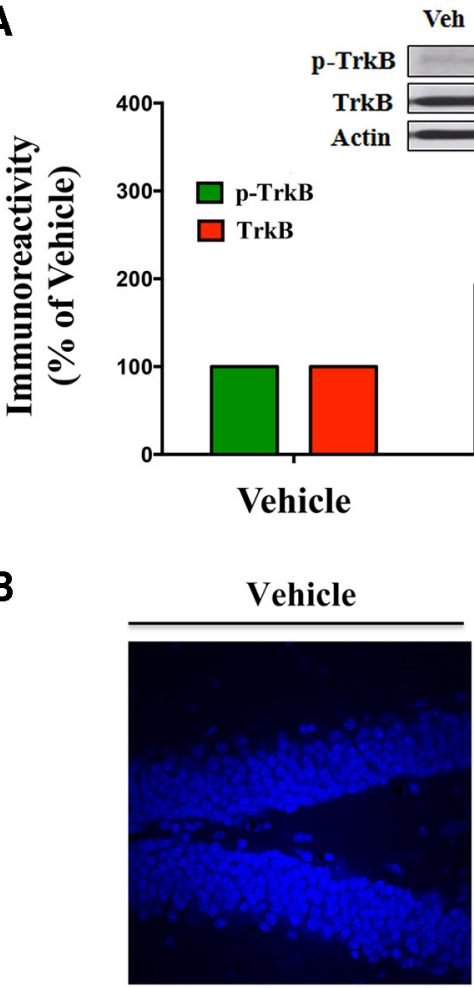

Veh $\quad 7,8-\mathrm{DHF}$

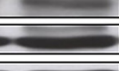

$* * *$
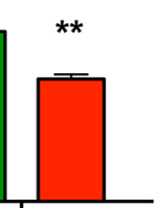

7,8-DHF

C

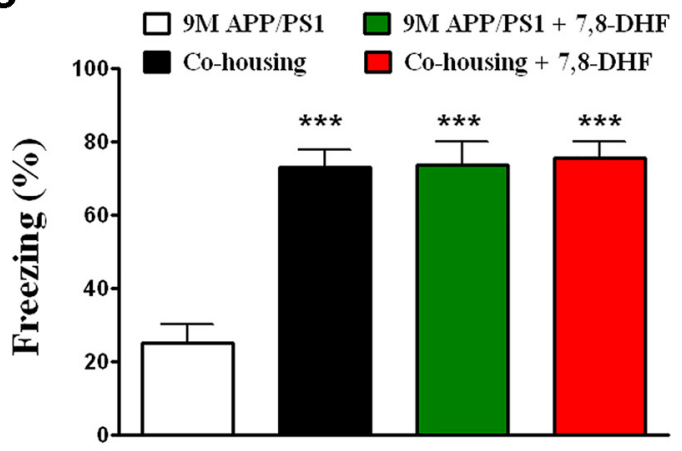

B

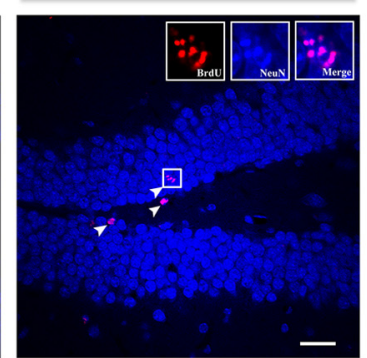

7,8-DHF

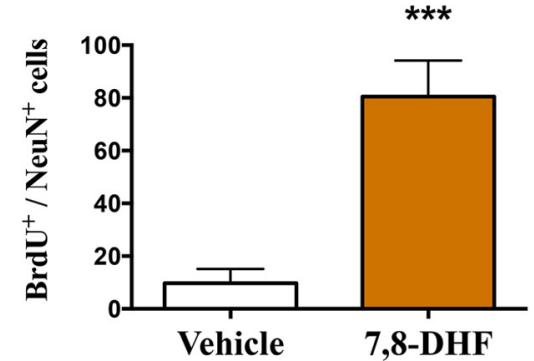

Figure 9. Effect of 7,8-DHF on cohousing-induced reversal of memory impairment. $\boldsymbol{A}, 7,8-\mathrm{DHF}(5 \mathrm{mg} / \mathrm{kg}$, i.p.) or a vehicle was injected to the mice once per day for $10 \mathrm{~d}$ before cohousing. The levels of phosphorylated TrkB and TrkB protein in the hippocampus were determined using Western blotting analysis ( $n=5$ in each group). ${ }^{* * *} p<0.001$ vs Vehicle. $\boldsymbol{B}$, After the treatment with 7,8-DHF (5 mg/kg, i.p.), the mice received an intraperitoneal injection of BrdU ( $300 \mathrm{mg} / \mathrm{kg}$ ) $2 \mathrm{~h}$ before cohousing and the BrdU ${ }^{+} / \mathrm{NeuN}^{+}$cells were analyzed after cohousing ( $n=4 \mathrm{in}$ each group). Sections were doubly labeled with BrdU (red) and NeuN (blue) immunofluorescence. Arrowheads in the 7,8-DHF group show BrdU-labeled neurons. Inserts show a higher magnification of the boxed area. Scale bar, $20 \mu \mathrm{m}$. C, Freezing responses of APP/PS1 mice with or without cohousing or 7,8-DHF treatment. In the 7,8-DHF-treated groups, APP/PS1 mice were injected with 7,8-DHF once per day for $10 \mathrm{~d}$ before cohousing ( $n=5$ in each group). ${ }^{* * *} p<0.001$ vs $9 \mathrm{~m}$ APP/PS1 mice.

7,8-DHF-treated mice than it was in vehicle-treated mice $\left(t_{(4)}=\right.$ $13.32, p=0.0002)$ after cohousing. Similarly, the TrkB protein level was also elevated in 7,8-DHF-treated mice $\left(t_{(4)}=7.230, p=0.0019\right)$. In parallel, more $\mathrm{BrdU}^{+} / \mathrm{NeuN}^{+}$cells were detected in 7,8-DHFtreated mice (Fig. 9B).

We compared freezing responses in 4 different mouse groups: $9 \mathrm{M} \mathrm{APP} / \mathrm{PS} 1$ (control), cohousing, $9 \mathrm{M}$ APP/PS1 plus 7,8-DHFtreated, and cohousing plus 7,8-DHF-treated. In the $9 \mathrm{M} A P P / P S 1$ plus 7,8-DHF-treated group, APP/PS1 mice were injected with 7,8-DHF once per day for $10 \mathrm{~d}$ without cohousing with WT mice. Figure $9 C$ reveals that freezing responses in the 3 groups with cohousing and/or 7,8-DHF treatment were significantly higher than those of control APP/PS1 mice. Furthermore, there was no difference among the three cohousing and/or 7,8-DHF treatment groups, suggesting that 7,8 -DHF occludes the cohousing effect.

\section{Discussion}

The present study sought to investigate the hypothesis that social interaction with a helper may have a beneficial effect on memory decline in AD. The results demonstrate that APP/PS1 mice perform better at cognitive tasks if their helpers interact with them more often. Furthermore, we suggest that the beneficial effect of companionship on the cognitive decline in this APP/PS1 model is mediated by increased BDNF expression and subsequent neurogenesis in the DG of the hippocampus.

In our previous study, we reported that social isolation exacerbated memory deficit in APP/PS1 mice by promoting endocytosis of AMPA receptors (Hsiao et al., 2011). Conversely, we show in the present study that social interaction with a helper reversed memory deficit in APP/PS1 mice. This conclusion is supported by the observation that there is a linear relationship between the interaction times of helpers and contextual freezing responses of 9-month-old APP/PS1 mice (after cohousing). In the social interaction study, weight matching animals is important because there is a possibility of having a dominant mouse in the cage. In addition, we rarely detected attack behaviors when the 6-monthold APP/PS1 mice were cohoused with younger helpers. Therefore, the possibility of having a dominant mouse in the cage could be excluded. It was also noted that the amygdala is typically implicated in paired context learning tasks. Indeed, we found that cued fear conditioning in 9-month-old APP/PS1 mice was also improved after cohousing with the 1-month-old WT mice (data not shown).

BDNF has pleiotropic effects on synaptic plasticity whereby it enhances neuronal LTP, neurogenesis, and cognitive function. Decreased BDNF expression and hippocampal neurogenesis have been associated with cognitive decline in aging. Postmortem studies have documented decreased BDNF, pro-BDNF, and $B d n f$ mRNA levels in the brains of patients diagnosed with $\mathrm{AD}$ and mild cognitive impairment (Phillips et al., 1991; Connor et al., 1997; O’Bryant et al., 2009). Furthermore, in aged rats and primates, BDNF infusion was shown to improve age-related perturbations in gene expression and ameliorate age-related cognitive impairment (Nagahara et al., 2009). Four lines of evidence derived from the current study support the hypothesis that increasing BDNF levels in the DG plays a critical role in mediating the beneficial effect of social interaction. First, APP/PS1 mice co- 
housed with helpers showed increased BDNF protein and mRNA levels. Second, knockdown of hippocampal BDNF level by transfection with $B d n f$ shRNA selectively eradicated cohousinginduced reversal of cognitive decline without affecting the freezing responses of control APP/PS1 mice. Third, overexpression of BDNF in the hippocampus mimicked cohousing induced reversal of cognitive decline in APP/PS1 mice. Finally, 7,8-DHF, a small-molecule TrkB agonist, also mimicked the effect of cohousing. More importantly, the effects of 7,8-DHF and cohousing occluded each other, suggesting that the cohousing effect is mediated by the BDNF-TrkB signal pathway.

It was noted that $B d n f$ shRNA transfection did not affect freezing responses in control APP/PS1 mice (Fig. 7E). This result was consistent with a previous study showing that BDNF knockdown in the DG caused a delay in spatial learning without affecting a subsequent memory probe test in the Morris water maze (Taliaz et al., 2010). It is likely that BDNF in the DG plays a critical role in depression but not in spatial memory (Taliaz et al., 2010). Only in the case of aging-induced and/or BDNF-deficiency-induced memory impairment do manipulations that increase BDNF and subsequent neurogenesis rescue memory decline.

The function of adult neurogenesis in the hippocampus remains a matter of debate. It has been suggested that adult neurogenesis is an important mechanism of plasticity related to learning and memory or even emotional or stress regulation (Jacobs et al., 2000; Snyder et al., 2011). In the present study, we found that social interaction with a helper increased $\mathrm{BrdU}^{+} /$ $\mathrm{NeuN}^{+}$cells in the DG of the hippocampus. Importantly, blocking of neurogenesis with MAM abolished companion-induced reversal of cognitive decline in APP/PS1 mice. Furthermore, selective ablation of mitotic neurons using a DT-DTR system abolished the beneficial effect of companionship. These results suggest that the beneficial effect of companionship on cognitive decline is mediated by BDNF-dependent adult neurogenesis in the DG. Therefore, it suggests that at least one function of adult neurogenesis in the DG is to resupply the active pool of neurons while the mature neurons degenerate and no longer function (Lisman, 2011).

Epidemiological studies in humans suggest that environmental influences including social interactions may delay the onset of dementia in $\mathrm{AD}$. Conversely, the risk of developing $\mathrm{AD}$ has been shown to be more than doubled in a lonely person (Wilson et al., 2007). In concert with these human studies, we found that social interaction with a helper effectively reversed memory deficits in APP/PS1 mice. More importantly, we demonstrated that the presence of a companion exerted its effect by increasing the level of BDNF and neurogenesis in the DG. These findings may make a valuable contribution to the development of strategies for management, prevention and treatment of $\mathrm{AD}$.

\section{References}

Arruda-Carvalho M, Sakaguchi M, Akers KG, Josselyn SA, Frankland PW (2011) Posttraining ablation of adult-generated neurons degrades previously acquired memories. J Neurosci 31:15113-15127. CrossRef Medline

Balu DT, Lucki I (2009) Adult hippocampal neurogenesis: regulation, functional implications, and contribution to disease pathology. Neurosci Biobehav Rev 33:232-252. CrossRef Medline

Barker GR, Warburton EC (2011) When is the hippocampus involved in recognition memory? J Neurosci 31:10721-10731. CrossRef Medline

Connor B, Young D, Yan Q, Faull RL, Synek B, Dragunow M (1997) Brainderived neurotrophic factor is reduced in Alzheimer's disease. Brain Res Mol Brain Res 49:71-81. CrossRef Medline

Devi L, Ohno M (2012) 7,8-dihydroxyflavone, a small-molecule TrkB agonist, reverses memory deficits and BACE1 elevation in a mouse model of
Alzheimer's disease. Neuropsychopharmacology 37:434-444. CrossRef Medline

Dorland RB, Middlebrook JL, Leppla SH (1979) Receptor-mediated internalization and degradation of diphtheria toxin by monkey kidney cells. J Biol Chem 254:11337-11342. Medline

Ferrer I, Marín C, Rey MJ, Ribalta T, Goutan E, Blanco R, Tolosa E, Martí E (1999) BDNF and full-length and truncated TrkB expression in Alzheimer disease. Implications in therapeutic strategies. J Neuropathol Exp Neurol 58:729-739. CrossRef Medline

Furukawa-Hibi Y, Nitta A, Ikeda T, Morishita K, Liu W, Ibi D, Alkam T, Nabeshima T, Yamada K (2011) The hydrophobic dipeptide Leu-Ile inhibits immobility induced by repeated forced swimming via the induction of BDNF. Behav Brain Res 220:271-280. CrossRef Medline

Han JH, Kushner SA, Yiu AP, Hsiang HL, Buch T, Waisman A, Bontempi B, Neve RL, Frankland PW, Josselyn SA (2009) Selective erasure of a fear memory. Science 323:1492-1496. CrossRef Medline

Hetman M, Kanning K, Cavanaugh JE, Xia Z (1999) Neuroprotection by brain-derived neurotrophic factor is mediated by extracellular signalregulated kinase and phosphatidylinositol 3-kinase. J Biol Chem 274: 22569-22580. CrossRef Medline

Hsiao YH, Chen PS, Chen SH, Gean PW (2011) The involvement of Cdk5 activator p35 in social isolation-triggered onset of early Alzheimer's disease-related cognitive deficit in the transgenic mice. Neuropsychopharmacology 36:1848-1858. CrossRef Medline

Imayoshi I, Sakamoto M, Ohtsuka T, Takao K, Miyakawa T, Yamaguchi M, Mori K, Ikeda T, Itohara S, Kageyama R (2008) Roles of continuous neurogenesis in the structural and functional integrity of the adult forebrain. Nat Neurosci 11:1153-1161. CrossRef Medline

Jacobs BL, van Praag H, Gage FH (2000) Adult brain neurogenesis and psychiatry: a novel theory of depression. Mol Psychiatry 5:262-269. CrossRef Medline

Jang SW, Liu X, Yepes M, Shepherd KR, Miller GW, Liu Y, Wilson WD, Xiao G, Blanchi B, Sun YE, Ye K (2010) A selective TrkB agonist with potent neurotrophic activities by 7,8-dihydroxyflavone. Proc Natl Acad Sci U S A 107:2687-2692. CrossRef Medline

Jankowsky JL, Fadale DJ, Anderson J, Xu GM, Gonzales V, Jenkins NA, Copeland NG, Lee MK, Younkin LH, Wagner SL, Younkin SG, Borchelt DR (2004) Mutant presenilins specifically elevate the levels of the 42 residue beta-amyloid peptide in vivo: evidence for augmentation of a 42 -specific gamma secretase. Hum Mol Genet 13:159-170. CrossRef Medline

Korte M, Carroll P, Wolf E, Brem G, Thoenen H, Bonhoeffer T (1995) Hippocampal long-term potentiation is impaired in mice lacking brainderived neurotrophic factor. Proc Natl Acad Sci U S A 92:8856-8860. CrossRef Medline

Lisman J (2011) Formation of the non-functional and functional pools of granule cells in the dentate gyrus: role of neurogenesis, LTP and LTD. J Physiol 589:1905-1909. CrossRef Medline

Lledo PM, Alonso M, Grubb MS (2006) Adult neurogenesis and functional plasticity in neuronal circuits. Nat Rev Neurosci 7:179-193. CrossRef Medline

Luchsinger JA, Mayeux R (2004) Dietary factors and Alzheimer's disease. Lancet Neurol 3:579-587. CrossRef Medline

McQuown SC, Barrett RM, Matheos DP, Post RJ, Rogge GA, Alenghat T, Mullican SE, Jones S, Rusche JR, Lazar MA, Wood MA (2011) HDAC3 is a critical negative regulator of long-term memory formation. J Neurosci 31:764-774. CrossRef Medline

Ming GL, Song H (2005) Adult neurogenesis in the mammalian central nervous system. Annu Rev Neurosci 28:223-250. CrossRef Medline

Mizuno M, Yamada K, Olariu A, Nawa H, Nabeshima T (2000) Involvement of brain-derived neurotrophic factor in spatial memory formation and maintenance in a radial arm maze test in rats. J Neurosci 20:71167121. Medline

Nagahara AH, Merrill DA, Coppola G, Tsukada S, Schroeder BE, Shaked GM, Wang L, Blesch A, Kim A, Conner JM, Rockenstein E, Chao MV, Koo EH, Geschwind D, Masliah E, Chiba AA, Tuszynski MH (2009) Neuroprotective effects of brain-derived neurotrophic factor in rodent and primate models of Alzheimer's disease. Nat Med 15:331-337. CrossRef Medline

Narisawa-Saito M, Wakabayashi K, Tsuji S, Takahashi H, Nawa H (1996) Regional specificity of alterations in NGF, BDNF and NT-3 levels in Alzheimer's disease. Neuroreport 7:2925-2928. CrossRef Medline

O'Bryant SE, Hobson V, Hall JR, Waring SC, Chan W, Massman P, Lacritz L, Cullum CM, Diaz-Arrastia R; Texas Alzheimer's Research Consortium 
(2009) Brain-derived neurotrophic factor levels in Alzheimer's disease. J Alzheimers Dis 17:337-341. CrossRef Medline

Pang PT, Teng HK, Zaitsev E, Woo NT, Sakata K, Zhen S, Teng KK, Yung WH, Hempstead BL, Lu B (2004) Cleavage of proBDNF by tPA/plasmin is essential for long-term hippocampal plasticity. Science 306:487-491. CrossRef Medline

Paradise M, Cooper C, Livingston G (2009) Systematic review of the effect of education on survival in Alzheimer's disease. Int Psychogeriatr 21:25-32. CrossRef Medline

Phillips HS, Hains JM, Armanini M, Laramee GR, Johnson SA, Winslow JW (1991) BDNF mRNA is decreased in the hippocampus of individuals with Alzheimer's disease. Neuron 7:695-702. CrossRef Medline

Saarelainen T, Hendolin P, Lucas G, Koponen E, Sairanen M, MacDonald E, Agerman K, Haapasalo A, Nawa H, Aloyz R, Ernfors P, Castrén E (2003) Activation of the TrkB neurotrophin receptor is induced by antidepressant drugs and is required for antidepressant-induced behavioral effects. J Neurosci 23:349-357. Medline

Sams-Dodd F (1995) Automation of the social interaction test by a videotracking system: behavioural effects of repeated phencyclidine treatment. J Neurosci Methods 59:157-167. CrossRef Medline

Saxe MD, Battaglia F, Wang JW, Malleret G, David DJ, Monckton JE, Garcia AD, Sofroniew MV, Kandel ER, Santarelli L, Hen R, Drew MR (2006) Ablation of hippocampal neurogenesis impairs contextual fear conditioning and synaptic plasticity in the dentate gyrus. Proc Natl Acad Sci U S A 103:17501-17506. CrossRef Medline

Shors TJ, Miesegaes G, Beylin A, Zhao M, Rydel T, Gould E (2001) Neurogenesis in the adult is involved in the formation of trace memories. Nature 410:372-376. CrossRef Medline

Shors TJ, Townsend DA, Zhao M, Kozorovitskiy Y, Gould E (2002) Neurogenesis may relate to some but not all types of hippocampal-dependent learning. Hippocampus 12:578-584. CrossRef Medline

Snigdha S, Neill JC (2008) Improvement of phencyclidine-induced social behaviour deficits in rats: involvement of 5-HT1A receptors. Behav Brain Res 191:26-31. CrossRef Medline

Snyder JS, Hong NS, McDonald RJ, Wojtowicz JM (2005) A role for adult neurogenesis in spatial long-term memory. Neuroscience 130:843-852. CrossRef Medline

Snyder JS, Soumier A, Brewer M, Pickel J, Cameron HA (2011) Adult hippocampal neurogenesis buffers stress responses and depressive behaviour. Nature 476:458-461. CrossRef Medline

Stefanko DP, Barrett RM, Ly AR, Reolon GK, Wood MA (2009) Modulation of long-term memory for object recognition via HDAC inhibition. Proc Natl Acad Sci U S A 106:9447-9452. CrossRef Medline

Stern Y (2006) Cognitive reserve and Alzheimer disease. Alzheimer Dis Assoc Disord 20:S69-74. CrossRef Medline

Szekely CA, Breitner JC, Zandi PP (2007) Prevention of Alzheimer's disease. Int Rev Psychiatry 19:693-706. CrossRef Medline

Taliaz D, Stall N, Dar DE, Zangen A (2010) Knockdown of brain-derived neurotropic factor in specific brain sites precipitates behavioral associated with depression and reduced neurogenesis. Mol Psychiatry 15:80-92. CrossRef Medline

Telerman A, Lapter S, Sharabi A, Zinger H, Mozes E (2011) Induction of hippocampal neurogenesis by a tolerogenic peptide that ameliorates lupus manifestations. J Neuroimmunol 232:151-157. CrossRef Medline

Tiraboschi P, Hansen LA, Thal LJ, Corey-Bloom J (2004) The importance of neuritic plaques and tangles to the development and evolution of $\mathrm{AD}$. Neurology 62:1984-1989. CrossRef Medline

Tokuyama W, Okuno H, Hashimoto T, Xin Li Y, Miyashita Y (2000) BDNF upregulation during declarative memory formation in monkey inferior temporal cortex. Nat Neurosci 3:1134-1142. CrossRef Medline

Trinchese F, Liu S, Battaglia F, Walter S, Mathews PM, Arancio O (2004) Progressive age-related development of Alzheimer-like pathology in APP/ PS1 mice. Ann Neurol 55:801-814. CrossRef Medline

Williams RW, Rakic P (1988) Three-dimensional counting: an accurate and direct method to estimate numbers of cells in sectioned material. J Comp Neurol 278:344-352. CrossRef Medline

Wilson RS, Krueger KR, Arnold SE, Schneider JA, Kelly JF, Barnes LL, Tang Y, Bennett DA (2007) Loneliness and risk of Alzheimer disease. Arch Gen Psychiatry 64:234-240. CrossRef Medline

Zuccato C, Cattaneo E (2009) Brain-derived neurotrophic factor in neurodegenerative diseases. Nat Rev Neurol 5:311-322. CrossRef Medline 